\title{
LEVEL II SCOUR ANALYSIS FOR BRIDGE 25 (ROYATH00550025) on TOWN HIGHWAY 55, crossing BROAD BROOK, ROYALTON, VERMONT
}

U.S. Geological Survey

Open-File Report 97-422

Prepared in cooperation with

VERMONT AGENCY OF TRANSPORTATION and

FEDERAL HIGHWAY ADMINISTRATION 


\section{LEVEL II SCOUR ANALYSIS FOR BRIDGE 25 (ROYATH00550025) on TOWN HIGHWAY 55, crossing BROAD BROOK, ROYALTON, VERMONT \\ By Ronda L. Burns and Matthew A. Weber}

U.S. Geological Survey Open-File Report 97-422

Prepared in cooperation with

VERMONT AGENCY OF TRANSPORTATION

and

FEDERAL HIGHWAY ADMINISTRATION 


\title{
U.S. DEPARTMENT OF THE INTERIOR BRUCE BABBITT, Secretary
}

\author{
U.S. GEOLOGICAL SURVEY \\ Gordon P. Eaton, Director
}

For additional information write to:

District Chief

U.S. Geological Survey 361 Commerce Way

Pembroke, NH 03275-3718
Copies of this report may be purchased from:

U.S. Geological Survey

Branch of Information Services

Open-File Reports Unit

Box 25286

Denver, CO 80225-0286 


\section{CONTENTS}

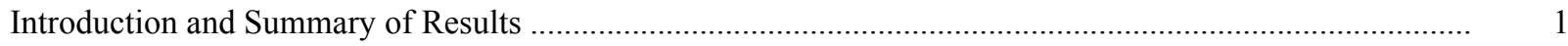

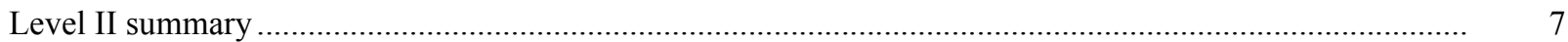

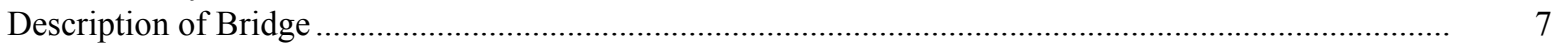

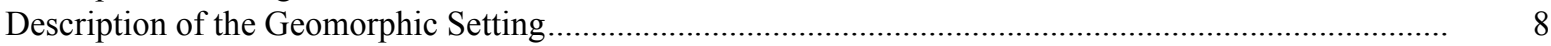

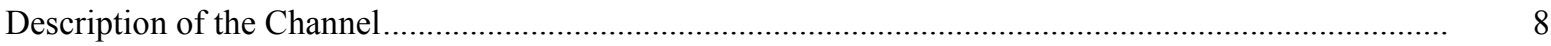

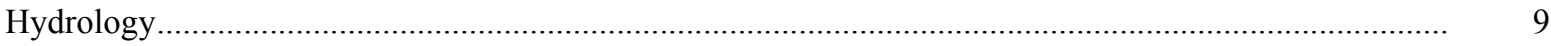

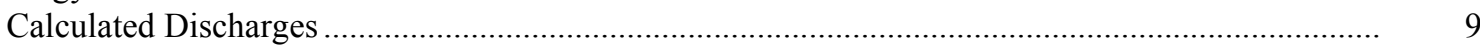

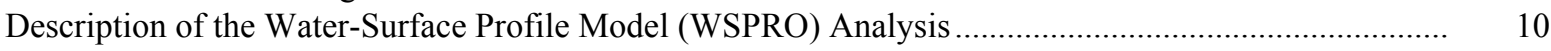

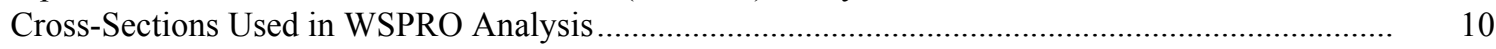

Data and Assumptions Used in WSPRO Model ...................................................................... 11

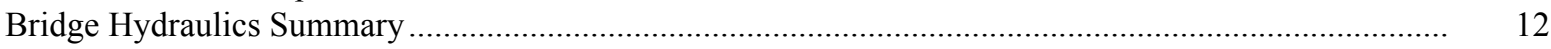

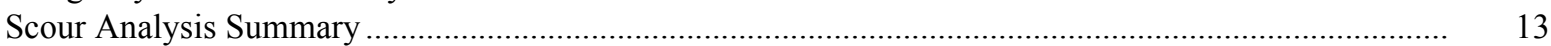

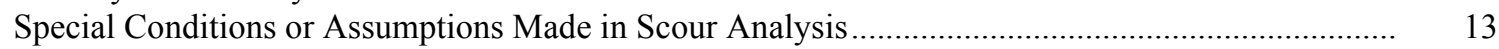

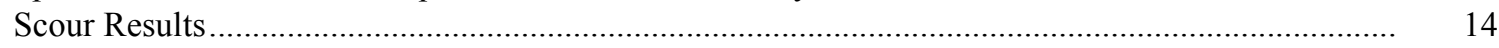

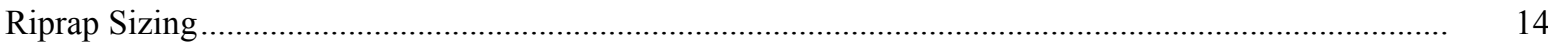

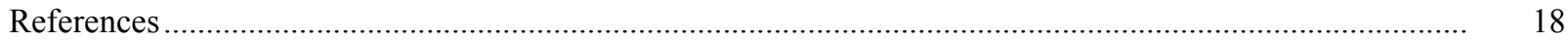

Appendixes:

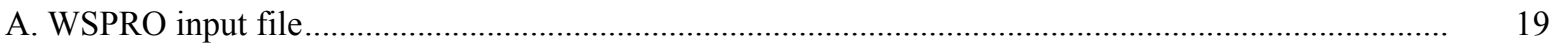

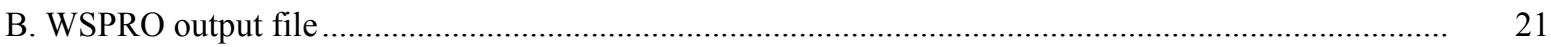

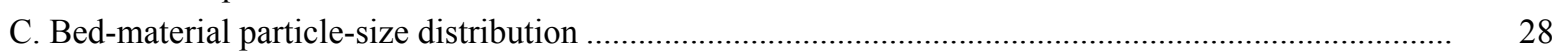

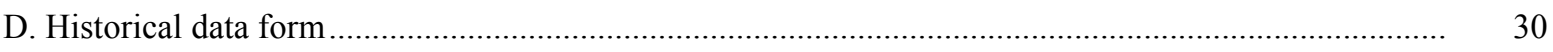

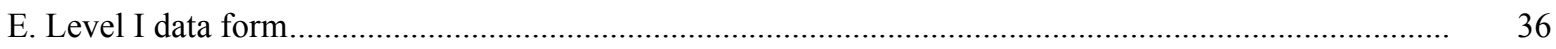

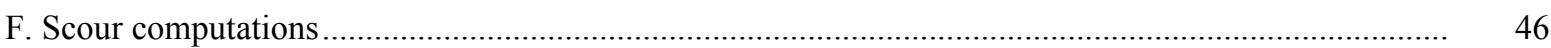

\section{FIGURES}

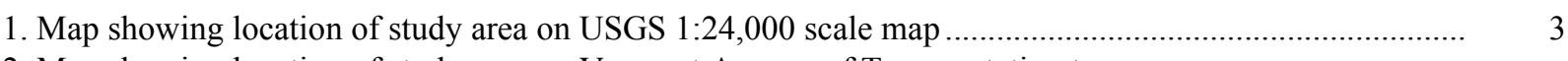

2. Map showing location of study area on Vermont Agency of Transportation town
highway map

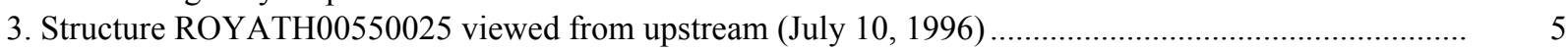

4. Downstream channel viewed from structure ROYATH00550025 (July 10, 1996). ................................ 5

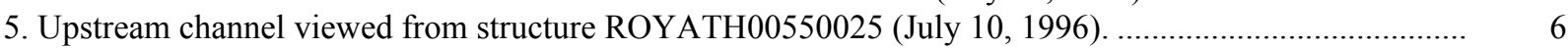

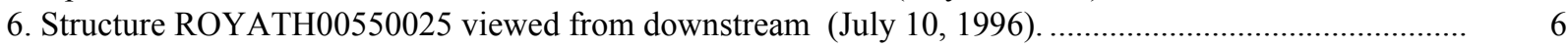

7. Water-surface profiles for the 100- and 500-year discharges at structure ROYATH00550025 on Town Highway 55, crossing Broad Brook,

Royalton, Vermont.

8. Scour elevations for the 100- and 500-year discharges at structure

ROYATH00550025 on Town Highway 55, crossing Broad Brook,

Royalton, Vermont.

\section{TABLES}

1. Remaining footing/pile depth at abutments for the 100-year discharge at structure ROYATH00550025 on Town Highway 55, crossing Broad Brook,

Royalton, Vermont...

2. Remaining footing/pile depth at abutments for the 500-year discharge at structure

ROYATH00550025 on Town Highway 55, crossing Broad Brook,

Royalton, Vermont. 


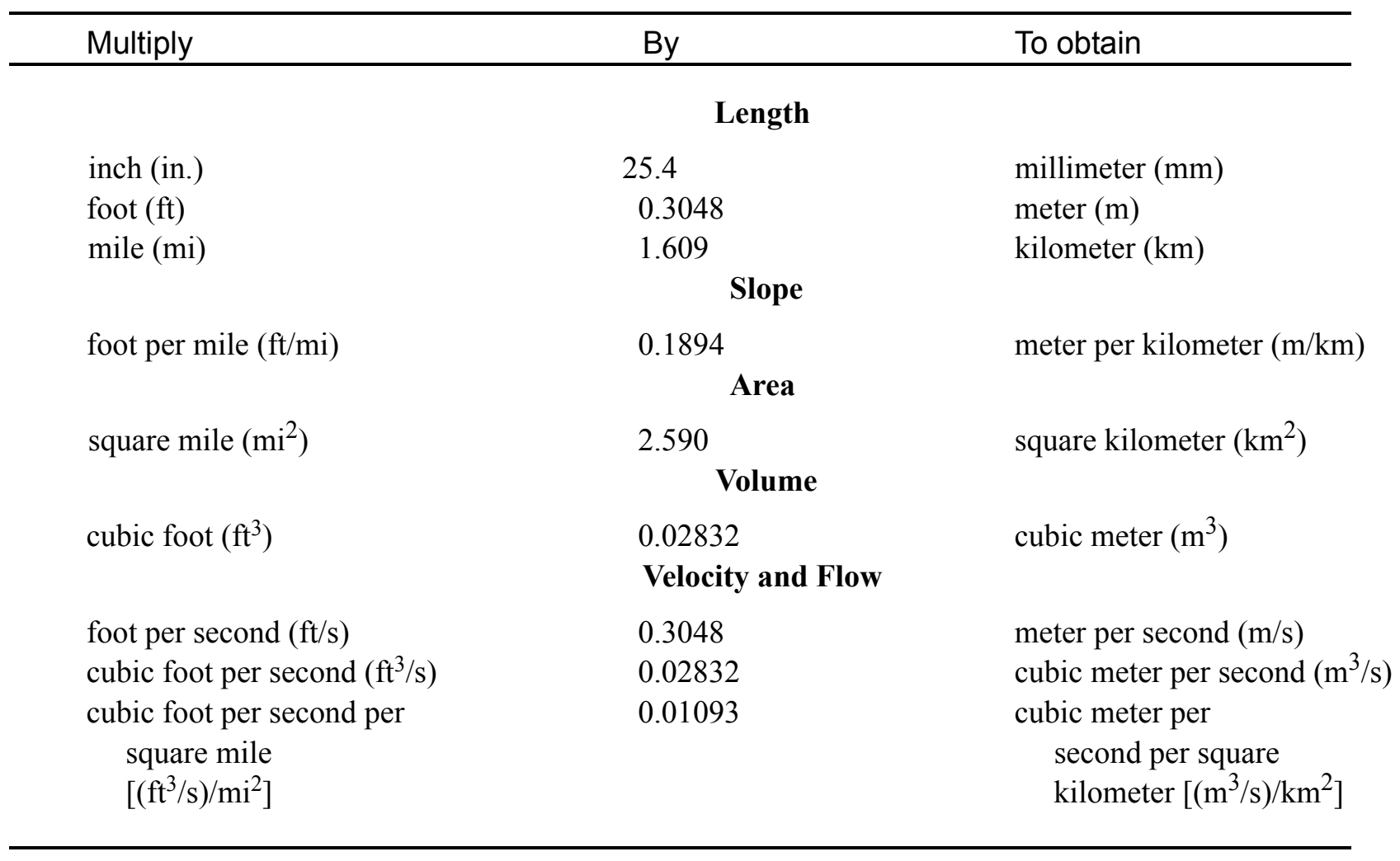

\section{OTHER ABBREVIATIONS}

$\begin{array}{lrlr}\mathrm{BF} & \text { bank full } & \text { LWW } & \text { left wingwall } \\ \mathrm{cfs} & \text { cubic feet per second } & \text { MC } & \text { main channel } \\ \mathrm{D}_{50} & \text { median diameter of bed material } & \text { RAB } & \text { right abutment } \\ \mathrm{DS} & \text { downstream } & \text { RABUT } & \text { face of right abutment } \\ \mathrm{elev} & \text { elevation } & \text { RB } & \text { right bank } \\ \mathrm{f} / \mathrm{p} & \text { flood plain } & \text { ROB } & \text { right overbank } \\ \mathrm{ft}^{2} & \text { square feet } & \text { RWW } & \text { right wingwall } \\ \mathrm{ft} / \mathrm{ft} & \text { feet per foot } & \text { TH } & \text { town highway } \\ \mathrm{JCT} & \text { junction } & \text { UB } & \text { under bridge } \\ \mathrm{LAB} & \text { left abutment } & \text { US } & \text { upstream } \\ \mathrm{LABUT} & \text { face of left abutment } & \text { USGS } & \text { United States Geological Survey } \\ \mathrm{LB} & \text { left bank } & \text { VTAOT Vermont Agency of Transportation } \\ \mathrm{LOB} & \text { left overbank } & \text { WSPRO } & \text { water-surface profile model }\end{array}$

In this report, the words "right" and "left" refer to directions that would be reported by an observer facing downstream. Sea level: In this report, "sea level" refers to the National Geodetic Vertical Datum of 1929-- a geodetic datum derived from a general adjustment of the first-order level nets of the United States and Canada, formerly called Sea Level Datum of 1929.

In the appendices, the above abbreviations may be combined. For example, USLB would represent upstream left bank. 


\title{
LEVEL II SCOUR ANALYSIS FOR BRIDGE 25 (ROYATH00550025) ON TOWN HIGHWAY 55, CROSSING BROAD BROOK, ROYALTON, VERMONT
}

\author{
By Ronda L. Burns and Matthew A. Weber
}

\section{INTRODUCTION AND SUMMARY OF RESULTS}

This report provides the results of a detailed Level II analysis of scour potential at structure ROYATH00550025 on Town Highway 55 crossing Broad Brook, Royalton, Vermont (figures 1-8). A Level II study is a basic engineering analysis of the site, including a quantitative analysis of stream stability and scour (U.S. Department of Transportation, 1993). Results of a Level I scour investigation also are included in Appendix E of this report. A Level I investigation provides a qualitative geomorphic characterization of the study site. Information on the bridge, gleaned from Vermont Agency of Transportation (VTAOT) files, was compiled prior to conducting Level I and Level II analyses and is found in Appendix D.

The site is in the New England Upland section of the New England physiographic province in central Vermont. The $11.6-\mathrm{mi}^{2}$ drainage area is in a predominantly rural and forested basin. In the vicinity of the study site, the surface cover is pasture on the upstream and downstream left overbanks and forest on the upstream and downstream right overbanks.

In the study area, Broad Brook has an incised, sinuous channel with a slope of approximately $0.01 \mathrm{ft} / \mathrm{ft}$, an average channel top width of $41 \mathrm{ft}$ and an average bank height of $5 \mathrm{ft}$. The channel bed material ranges from sand to boulder with a median grain size $\left(\mathrm{D}_{50}\right)$ of $58.3 \mathrm{~mm}(0.191 \mathrm{ft})$. The geomorphic assessment at the time of the Level I site visit on April 13, 1995 indicated that the reach was laterally unstable. The stream impacts the upstream left bank where there is a cut bank.

The Town Highway 55 crossing of the Broad Brook is a 35-ft-long, two-lane bridge consisting of one 31-foot steel-beam span (Vermont Agency of Transportation, written communication, March 22, 1995). The opening length of the structure parallel to the bridge face is $32 \mathrm{ft}$. The bridge is supported by vertical, concrete abutments with wingwalls. The channel is skewed approximately 20 degrees to the opening, while the opening-skew-toroadway is zero degrees. 
A scour hole $1.0 \mathrm{ft}$ deeper than the mean thalweg depth was observed along the left abutment and the downstream left wingwall during the Level I assessment. The scour countermeasure at the site was type- 2 stone fill (less than 36 inches diameter) along the upstream and downstream left banks that extended to the ends of the wingwalls.

Additional details describing conditions at the site are included in the Level II Summary and Appendices D and E.

Scour depths and recommended rock rip-rap sizes were computed using the general guidelines described in Hydraulic Engineering Circular 18 (Richardson and others, 1995). Total scour at a highway crossing is comprised of three components: 1) long-term streambed degradation; 2) contraction scour (due to accelerated flow caused by a reduction in flow area at a bridge) and; 3 ) local scour (caused by accelerated flow around piers and abutments). Total scour is the sum of the three components. Equations are available to compute depths for contraction and local scour and a summary of the results of these computations follows.

Contraction scour for all modelled flows ranged from 0.6 to $1.5 \mathrm{ft}$. The worst-case contraction scour occurred at the incipient-overtopping discharge which was less than the 100 -year discharge. Abutment scour ranged from 3.5 to $8.9 \mathrm{ft}$. The worst-case abutment scour occurred at the incipient road-overtopping discharge for the left abutment and at the 100 -year discharge for the right abutment. Additional information on scour depths and depths to armoring are included in the section titled "Scour Results". Scoured-streambed elevations, based on the calculated scour depths, are presented in tables 1 and 2. A crosssection of the scour computed at the bridge is presented in figure 8. Scour depths were calculated assuming an infinite depth of erosive material and a homogeneous particle-size distribution.

It is generally accepted that the Froehlich equation (abutment scour) gives "excessively conservative estimates of scour depths" (Richardson and others, 1995, p. 47). Usually, computed scour depths are evaluated in combination with other information including (but not limited to) historical performance during flood events, the geomorphic stability assessment, existing scour protection measures, and the results of the hydraulic analyses. Therefore, scour depths adopted by VTAOT may differ from the computed values documented herein. 


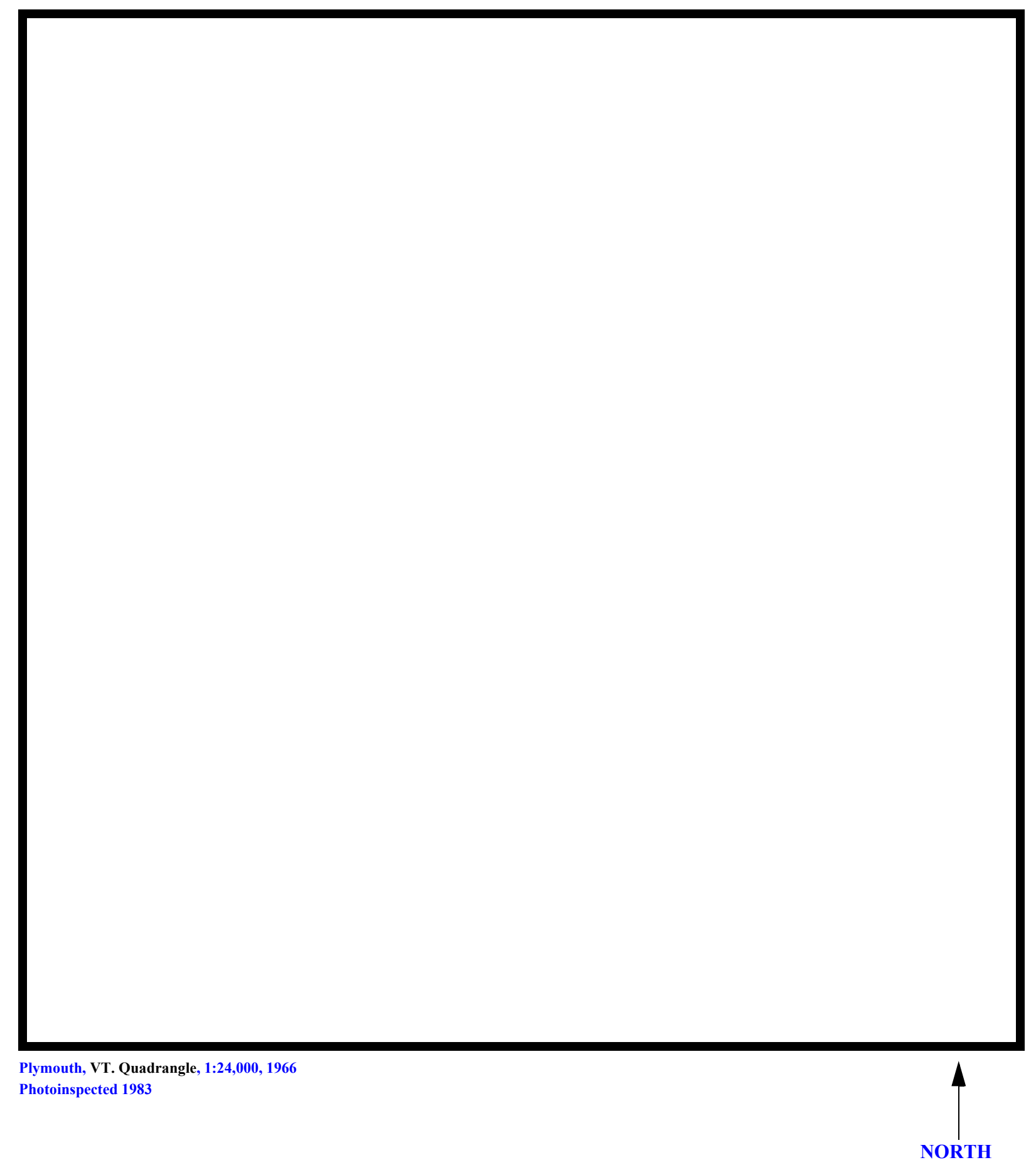

Figure 1. Location of study area on USGS 1:24,000 scale map. 
Figure 2. Location of study area on Vermont Agency of Transportation town highway map. 

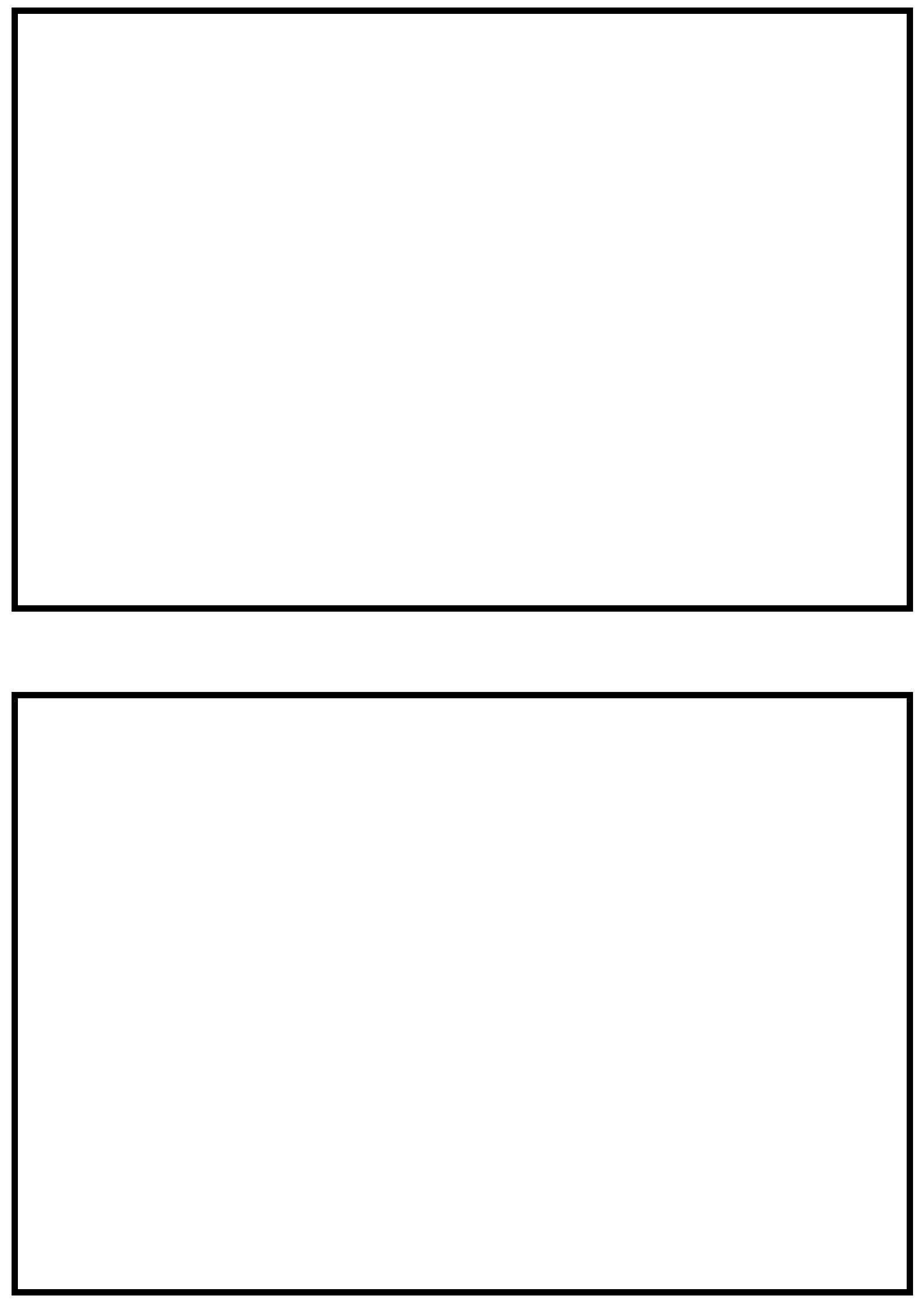

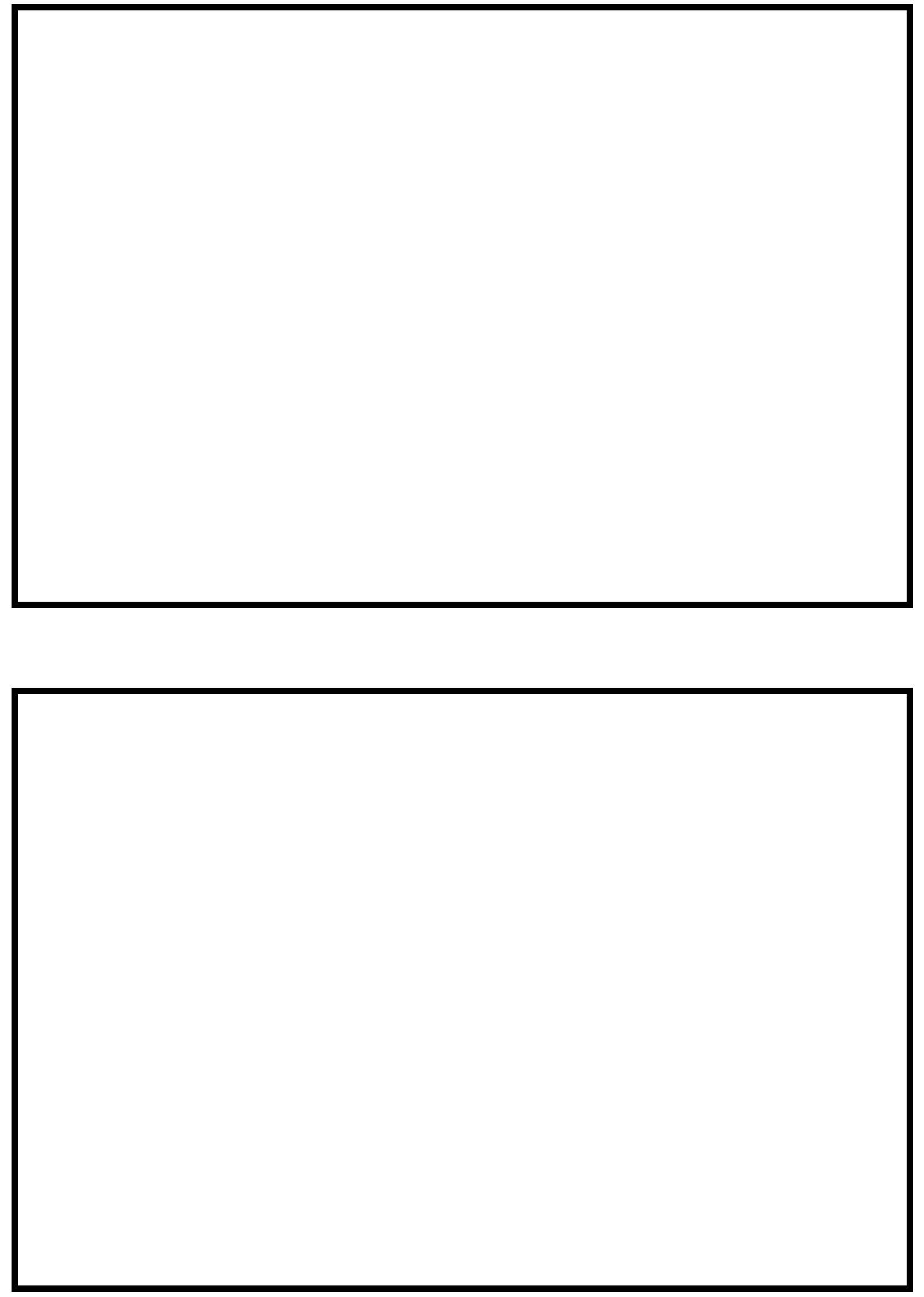


\section{Description of the Geomorphic Setting}

General topography The channel is located within a moderate relief valley.

Geomorphic conditions at bridge site: downstream (DS), upstream (US)

Date of inspection $\quad 04 / 13 / 95$

DS left: $\quad$ Steep channel bank to a mildly sloped overbank to the valley wall.

DS right: $\quad$ Moderately sloped overbank.

US left: $\quad$ Steep channel bank to a mildly sloped overbank to the valley wall.

US right: $\quad$ Moderately sloped overbank.

\section{Description of the Channel}

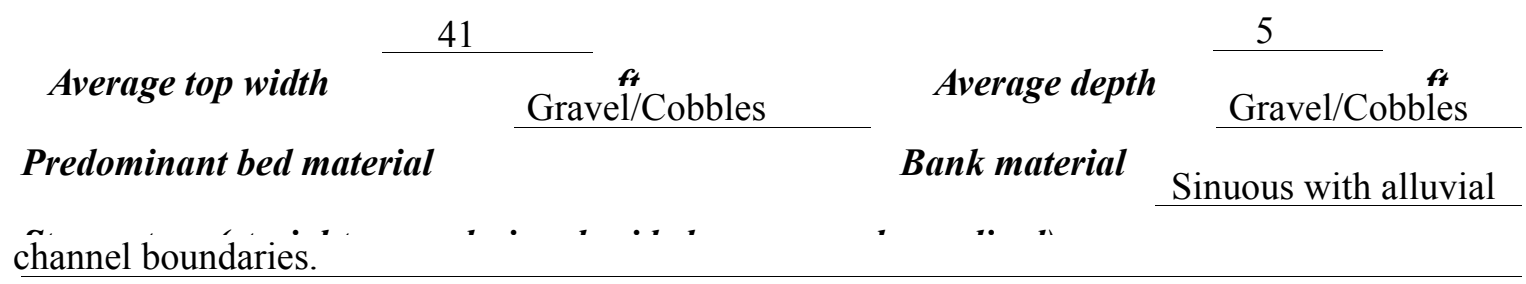

$04 / 13 / 95$

Vegetative co ${ }^{1}$ Short grass with brush along the immédiate bank.

DS left: $\quad$ Trees and brush.

DS right: $\quad$ Short grass with brush along the immediate bank.

US left: $\quad$ Trees and brush.

US right:

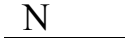

Do banks appear stable? There is a cut bank on the upstream left bank where the road an date of observation.

None. $04 / 13 / 95$

Describe any obstructions in channel and date of observation. 


\section{Hydrology}

Drainage area $\frac{11.6}{m^{2}}{ }^{2}$

Percentage of drainage area in physiographic provinces: (approximate)

Physiographic province/section New England/New England Upland
Percent of drainage area 100

Is drainage area considered rural or urban? — Rural _ Describe any significant urbanization:

Is there a USGS gage on the stream of interest?

No

USGS gage description

USGS gage number

Gage drainage area $\mathrm{mi}^{2}$

Is there a lake/p

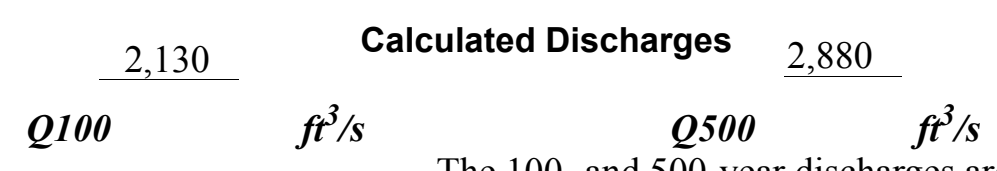

The 100- and 500-year discharges are based on the

median yalue within a range defined by flood frequency curves developed from several empirical methods. (Benson, 1962; Johnson and Tasker, 1974; FHWA, 1983; Potter, 1957a\&b; Talbot, 1887) 


\section{Description of the Water-Surface Profile Model (WSPRO) Analysis}

Datum for WSPRO analysis (USGS survey, sea level, VTAOT plans)

USGS survey

Datum tie between USGS survey and VTAOT plans

None

Description of reference marks used to determine USGS datum. $\quad$ RM1 is a chiseled X on top of the upstream end of the left abutment (elev. $498.85 \mathrm{ft}$, arbitrary survey datum). RM2 is a chiseled X on top of the downstream end of the right abutment (elev. $498.50 \mathrm{ft}$, arbitrary survey datum).

\section{Cross-Sections Used in WSPRO Analysis}

\begin{tabular}{|c|c|c|c|}
\hline${ }^{1}$ Cross-section & $\begin{array}{c}\text { Section } \\
\text { Reference } \\
\text { Distance } \\
\text { (SRD) in feet }\end{array}$ & $\begin{array}{c}{ }^{2} \text { Cross-section } \\
\text { development }\end{array}$ & Comments \\
\hline EXITX & -32 & 1 & Exit section \\
\hline FULLV & 0 & 2 & $\begin{array}{l}\text { Downstream Full-valley } \\
\text { section (Templated from } \\
\text { EXITX) }\end{array}$ \\
\hline BRIDG & 0 & 1 & Bridge section \\
\hline RDWAY & 8 & 1 & Road Grade section \\
\hline APPRO & 49 & 1 & Approach section \\
\hline
\end{tabular}

${ }^{1}$ For location of cross-sections see plan-view sketch included with Level I field form, Appendix E. For more detail on how cross-sections were developed see WSPRO input file. 


\section{Data and Assumptions Used in WSPRO Model}

Hydraulic analyses of the reach were done by use of the Federal Highway Administration's WSPRO step-backwater computer program (Shearman and others, 1986, and Shearman, 1990). The analyses reported herein reflect conditions existing at the site at the time of the study. Furthermore, in the development of the model it was necessary to assume no accumulation of debris or ice at the site. Results of the hydraulic model are presented in the Bridge Hydraulic Summary, Appendix B, and figure 7.

Channel roughness factors (Manning's " $n$ ") used in the hydraulic model were estimated using field inspections at each cross section following the general guidelines described by Arcement and Schneider (1989). Final adjustments to the values were made during the modelling of the reach. Channel " $n$ " values for the reach ranged from 0.035 to 0.055 , and overbank " $\mathrm{n}$ " values ranged from 0.035 to 0.065 .

Normal depth at the exit section (EXITX) was assumed as the starting water surface. This depth was computed by use of the slope-conveyance method outlined in the user's manual for WSPRO (Shearman, 1990). The slope used was $0.0106 \mathrm{ft} / \mathrm{ft}$ which was estimated from the surveyed points downstream (Level II assessment 07/10/96).

The surveyed approach section (APPRO) was one bridge length upstream of the upstream face as recommended by Shearman and others (1986). This location also provides a consistent method for determining scour variables.

For the incipient-overtopping discharge, WSPRO assumes critical depth at the bridge section. A supercritical model was developed for this discharge. After analyzing both the supercritical and subcritical profiles for this discharge, it can be determined that the water surface profile does pass through critical depth within the bridge opening. Thus, the assumption of critical depth at the bridge is a satisfactory solution. 


\section{Bridge Hydraulics Summary}

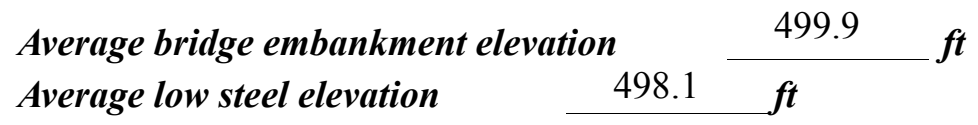

100-year discharge $\quad 2,130 \quad \mathrm{ft}^{3} / \mathrm{s}$

Water-surface elevation in bridge opening $498.1 \quad f t$

Road overtopping? ___ Y Discharge over road __ 216 $\mathrm{ft}^{3} / \mathrm{s}$

\begin{tabular}{llll} 
Area of flow in bridge opening & 207 & $\boldsymbol{f t}^{2}$ \\
\cline { 2 - 3 } Average velocity in bridge opening & 9.3 & $\boldsymbol{f t} / \mathrm{s}$
\end{tabular}

$\begin{array}{llll}\text { Maximum WSPRO tube velocity at bridge } & 10.7 \quad \mathrm{ft} / \mathrm{s}\end{array}$

Water-surface elevation at Approach section with bridge $\quad 500.4$

$\begin{array}{ll}\text { Water-surface elevation at Approach section without bridge } & 497.7\end{array}$

Amount of backwater caused by bridge

$2.7 \quad i$

500-year discharge $\quad 2,880 \quad \mathrm{ft}^{3} / \mathrm{s}$

Water-surface elevation in bridge opening

$498.1 \mathrm{ft}$

Road overtopping? ___ Y Discharge over road _ $\quad 810 \quad \mathrm{ft}^{3} / \mathrm{s}$

Area of flow in bridge opening $\quad 206 \quad \mathrm{ft}^{2}$

Average velocity in bridge opening $10.2 \mathrm{ft} / \mathrm{s}$

Maximum WSPRO tube velocity at bridge 14.1 's

Water-surface elevation at Approach section with bridge 501.2

Water-surface elevation at Approach section without bridge $\quad 498.8$

Amount of backwater caused by bridge $\quad 2.4$.t

Incipient overtopping discharge $\quad 1,940 \mathrm{ft}^{3} / \mathrm{s}$

Water-surface elevation in bridge opening $496.4 \quad t$

Area of flow in bridge opening $\quad 154 \quad \mathrm{ft}^{2}$

Average velocity in bridge opening $\quad 12.6 \quad \mathrm{ft} / \mathrm{s}$

Maximum WSPRO tube velocity at bridge $\quad 14.9 \quad \mathrm{ft} / \mathrm{s}$

Water-surface elevation at Approach section with bridge

Water-surface elevation at Approach section without bridge

498.5

Amount of backwater caused by bridge $\quad$\begin{tabular}{ll}
0.9 \\
\hline
\end{tabular} 


\section{Scour Analysis Summary}

\section{Special Conditions or Assumptions Made in Scour Analysis}

Scour depths were computed using the general guidelines described in Hydraulic Engineering Circular 18 (Richardson and others, 1995). Scour depths were calculated assuming an infinite depth of erosive material and a homogeneous particle-size distribution. The results of the scour analysis are presented in tables 1 and 2 and a graph of the scour depths is presented in figure 8 .

Contraction scour for the incipient-overtopping discharge was computed by use of the clearwater contraction scour equation (Richardson and others, 1995, p. 32, equation 20). At this site, the 100-year and the 500-year discharges resulted in unsubmerged orifice flow. Contraction scour at bridges with orifice flow is best estimated by use of the Chang pressure-flow scour equation (oral communication, J. Sterling Jones, October 4, 1996). Thus, contraction scour for these discharges was computed by use of the Chang equation (Richardson and others, 1995, p. 145-146). The streambed armoring depths computed suggest that armoring will not limit the depth of contraction scour.

For comparison to the Chang equation results, estimates of contraction scour for the 100 - and 500-year discharges were also computed by use of the Laursen and Umbrell (Richardson and others, 1995, p. 144) scour equations and the results are presented in Appendix F. Furthermore, additional estimates of contraction scour were computed by substituting alternative estimates for the depth of flow in the bridge at the downstream face into the equations. Contraction scour results with respect to these substitutions also are provided in Appendix F.

Abutment scour for the incipient road-overtopping discharge and at the right abutment for the 100-year and 500-year discharges was computed by use of the Froehlich equation (Richardson and others, 1995, p. 48, equation 28). Variables for the Froehlich equation include the Froude number of the flow approaching the embankments, the length of the embankment blocking flow, and the depth of flow approaching the embankment less any roadway overtopping.

Scour at the left abutment for the 100-year and 500-year discharges was computed by use of the HIRE equation (Richardson and others, 1995, p. 49, equation 29) because the HIRE equation is recommended when the length to depth ratio of the embankment blocking flow exceeds 25 . The variables used by the HIRE abutment-scour equation are defined the same as those defined for the Froehlich abutment-scour equation. 


\section{Scour Results}

$$
\text { 100-yr discharge 500-yr discharge }
$$

Contraction scour:

(Scour depths in feet)

Main channel

Live-bed scour

Clear-water scour

Depth to armoring

Left overbank

Right overbank

Local scour:

Abutment scour

Left abutment

Right abutment

Pier scour

Pier 1

Pier 2

Pier 3
3.5

8.9-
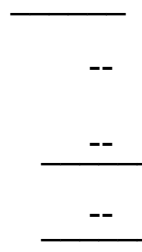

4.4

$8.0-$
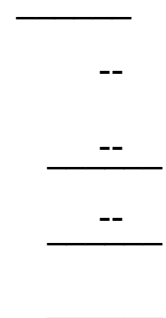

Incipient overtopping discharge 


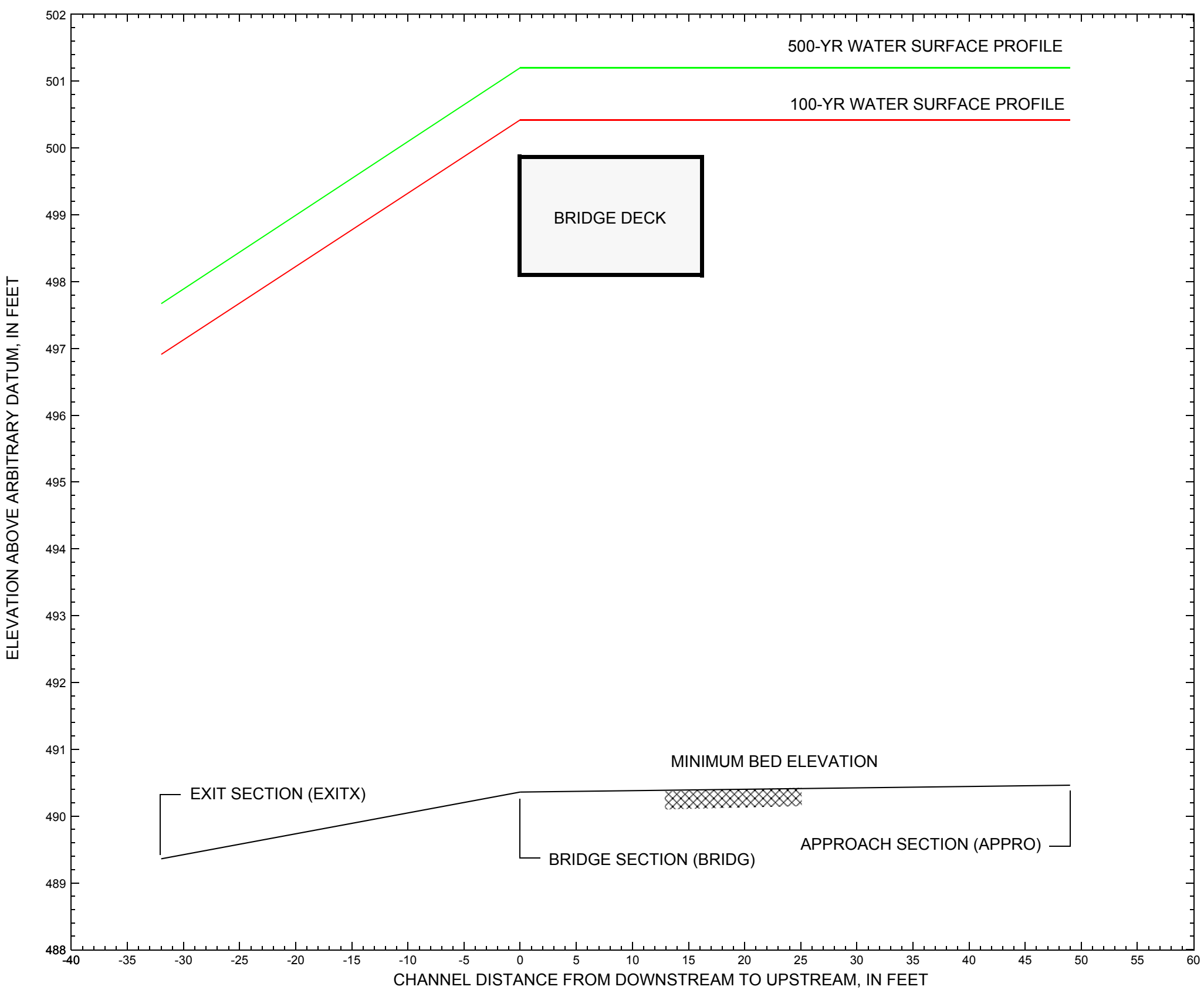

Figure 7. Water-surface profiles for the 100- and 500-yr discharges at structure ROYATH00550025 on Town Highway 55, crossing Broad Brook, Royalton, Vermont. 


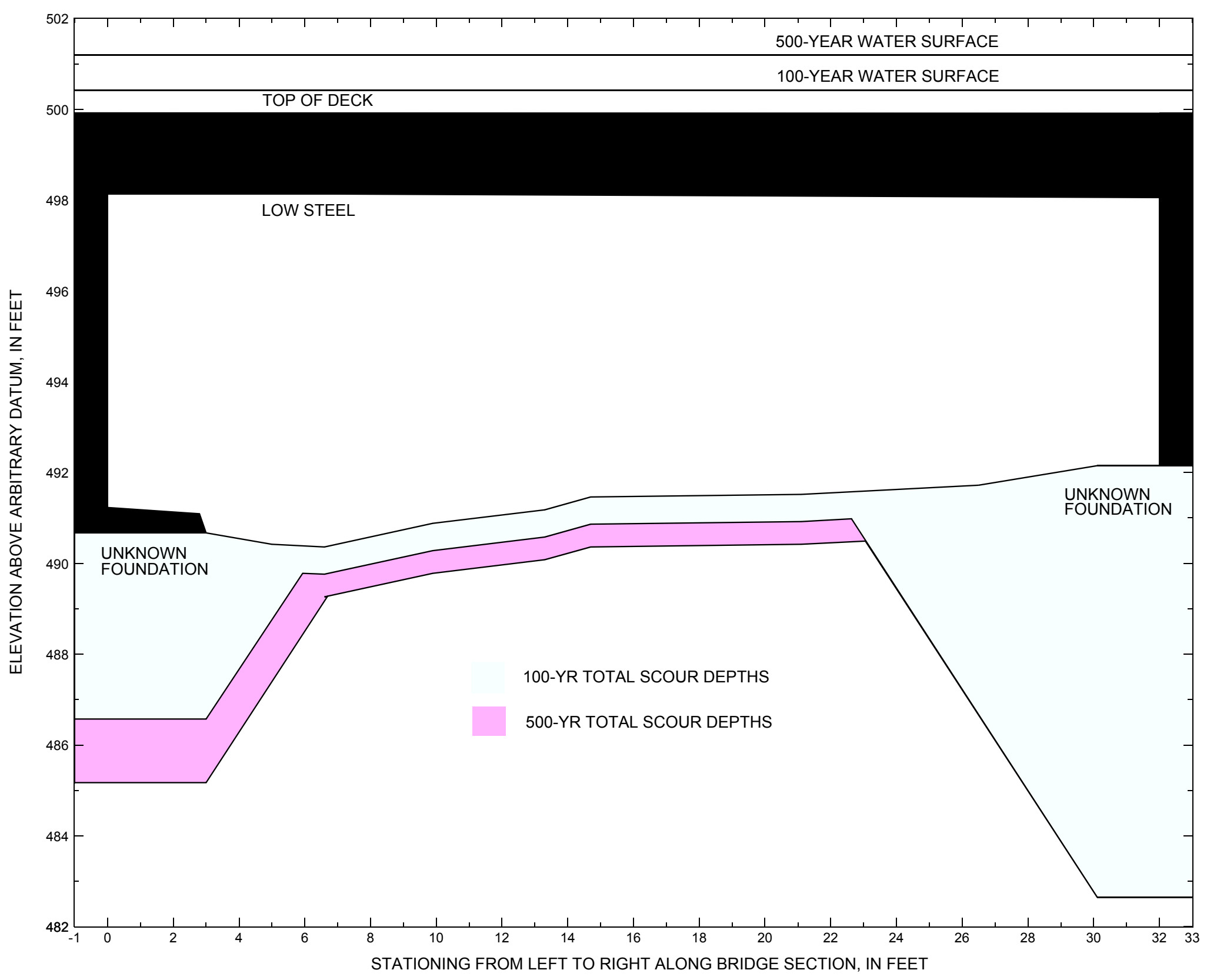

Figure 8. Scour elevations for the 100-yr and 500-yr discharges at structure ROYATH00550025 on Town Highway 55, crossing Broad Brook, Royalton, Vermont. 
Table 1. Remaining footing/pile depth at abutments for the 100-year discharge at structure ROYATH00550025 on Town Highway 55, crossing Broad Brook, Vermont.

[VTAOT, Vermont Agency of Transportation; --, no data]

\begin{tabular}{|c|c|c|c|c|c|c|c|c|c|c|c|}
\hline Description & Station $^{1}$ & $\begin{array}{l}\text { VTAOT } \\
\text { minimum } \\
\text { low-chord } \\
\text { elevation } \\
\text { (feet) }\end{array}$ & $\begin{array}{c}\text { Surveyed } \\
\text { minimum } \\
\text { low-chord } \\
\text { elevation } \\
\text { (feet) }\end{array}$ & $\begin{array}{c}\text { Bottom of } \\
\text { footing } \\
\text { elevation } \\
\text { (feet) }\end{array}$ & $\begin{array}{c}\text { Channel } \\
\text { elevation at } \\
\text { abutment/ } \\
\text { pier }^{2} \\
\text { (feet) }\end{array}$ & $\begin{array}{l}\text { Contraction } \\
\text { scour depth } \\
\text { (feet) }\end{array}$ & $\begin{array}{l}\text { Abutment } \\
\text { scour } \\
\text { depth } \\
\text { (feet) }\end{array}$ & $\begin{array}{l}\text { Pier } \\
\text { scour } \\
\text { depth } \\
\text { (feet) }\end{array}$ & $\begin{array}{l}\text { Depth of } \\
\text { total scour } \\
\text { (feet) }\end{array}$ & $\begin{array}{c}\text { Elevation of } \\
\text { scour }^{2} \\
\text { (feet) }\end{array}$ & $\begin{array}{c}\text { Remaining } \\
\text { footing/pile } \\
\text { depth } \\
\text { (feet) }\end{array}$ \\
\hline \multicolumn{12}{|c|}{100 -yr. discharge is 2,125 cubic-feet per second } \\
\hline Left abutment & 0.0 & -- & 498.1 & -- & 490.7 & 0.6 & 3.5 & -- & 4.1 & 486.6 & -- \\
\hline Right abutment & 32.0 & -- & 498.0 & -- & 492.2 & 0.6 & 8.9 & -- & 9.5 & 482.7 & -- \\
\hline
\end{tabular}

1.Measured along the face of the most constricting side of the bridge.

2.Arbitrary datum for this study.

Table 2. Remaining footing/pile depth at abutments for the 500-year discharge at structure ROYATH00550025 on Town Highway 55, crossing Broad Brook, Vermont.

[VTAOT, Vermont Agency of Transportation; --, no data]

\begin{tabular}{|c|c|c|c|c|c|c|c|c|c|c|c|}
\hline Description & Station $^{1}$ & $\begin{array}{l}\text { VTAOT } \\
\text { minimum } \\
\text { low-chord } \\
\text { elevation } \\
\text { (feet) }\end{array}$ & $\begin{array}{l}\text { Surveyed } \\
\text { minimum } \\
\text { low-chord } \\
\text { elevation } \\
\text { (feet) }\end{array}$ & $\begin{array}{l}\text { Bottom of } \\
\text { footing } \\
\text { elevation } \\
\text { (feet) }\end{array}$ & $\begin{array}{c}\text { Channel } \\
\text { elevation at } \\
\text { abutment/ } \\
\text { pier }^{2} \\
\text { (feet) }\end{array}$ & $\begin{array}{l}\text { Contraction } \\
\text { scour depth } \\
\text { (feet) }\end{array}$ & $\begin{array}{l}\text { Abutment } \\
\text { scour } \\
\text { depth } \\
\text { (feet) }\end{array}$ & $\begin{array}{l}\text { Pier } \\
\text { scour } \\
\text { depth } \\
\text { (feet) }\end{array}$ & $\begin{array}{l}\text { Depth of } \\
\text { total scour } \\
\text { (feet) }\end{array}$ & $\begin{array}{c}\text { Elevation of } \\
\text { scour }^{2} \\
\text { (feet) }\end{array}$ & $\begin{array}{c}\text { Remaining } \\
\text { footing/pile } \\
\text { depth } \\
\text { (feet) }\end{array}$ \\
\hline \multicolumn{12}{|c|}{500 -yr. discharge is 2,875 cubic-feet per second } \\
\hline Left abutment & 0.0 & -- & 498.1 & -- & 490.7 & 1.1 & 4.4 & -- & 5.5 & 485.2 & -- \\
\hline Right abutment & 32.0 & -- & 498.0 & -- & 492.2 & 1.1 & 8.0 & -- & 9.1 & 483.1 & -- \\
\hline
\end{tabular}

1.Measured along the face of the most constricting side of the bridge.

2.Arbitrary datum for this study. 


\section{SELECTED REFERENCES}

Arcement, G.J., Jr., and Schneider, V.R., 1989, Guide for selecting Manning's roughness coefficients for natural channels and flood plains: U.S. Geological Survey Water-Supply Paper 2339, 38 p.

Barnes, H.H., Jr., 1967, Roughness characteristics of natural channels: U.S. Geological Survey Water-Supply Paper 1849,213 p.

Benson, M. A., 1962, Factors Influencing the Occurrence of Floods in a Humid Region of Diverse Terrain: U.S. Geological Survey WaterSupply Paper 1580-B, 64 p.

Brown, S.A. and Clyde, E.S., 1989, Design of riprap revetment: Federal Highway Administration Hydraulic Engineering Circular No. 11, Publication FHWA-IP-89-016, 156 p.

Federal Highway Administration, 1983, Runoff estimates for small watersheds and development of sound design: Federal Highway Administration Report FHWA-RD-77-158.

Federal Highway Administration, 1993, Stream Stability and Scour at Highway Bridges: Participant Workbook: Federal Highway Administration Report FHWA-HI-91-011.

Froehlich, D.C., 1989, Local scour at bridge abutments in Ports, M.A., ed., Hydraulic Engineering--Proceedings of the 1989 National Conference on Hydraulic Engineering: New York, American Society of Civil Engineers, p. 13-18.

Hayes, D.C.,1993, Site selection and collection of bridge-scour data in Delaware, Maryland, and Virginia: U.S. Geological Survey WaterResources Investigation Report 93-4017, 23 p.

Interagency Advisory Committee on Water Data, 1982, Guidelines for determining flood flow frequency: U.S. Geological Survey, Bulletin 17B of the Hydrology Subcommittee, 190 p.

Johnson, C.G. and Tasker, G.D.,1974, Progress report on flood magnitude and frequency of Vermont streams: U.S. Geological Survey OpenFile Report 74-130, 37 p.

Lagasse, P.F., Schall, J.D., Johnson, F., Richardson, E.V., Chang, F., 1995, Stream Stability at Highway Structures: Federal Highway Administration Hydraulic Engineering Circular No. 20, Publication FHWA-IP-90-014, 144 p.

Laursen, E.M., 1960, Scour at bridge crossings: Journal of the Hydraulics Division, American Society of Civil Engineers, v. 86, no. HY2, p. 39-53.

Potter, W. D., 1957a, Peak rates of runoff in the Adirondack, White Mountains, and Maine woods area, Bureau of Public Roads

Potter, W. D., 1957b, Peak rates of runoff in the New England Hill and Lowland area, Bureau of Public Roads

Richardson, E.V. and Davis, S.R., 1995, Evaluating scour at bridges: Federal Highway Administration Hydraulic Engineering Circular No. 18, Publication FHWA-IP-90-017, 204 p.

Richardson, E.V., Simons, D.B., and Julien, P.Y., 1990, Highways in the river environment: Federal Highway Administration Publication FHWA-HI-90-016.

Ritter, D.F., 1984, Process Geomorphology: W.C. Brown Co., Debuque, Iowa, 603 p.

Shearman, J.O., 1990, User's manual for WSPRO--a computer model for water surface profile computations: Federal Highway Administration Publication FHWA-IP-89-027, 187 p.

Shearman, J.O., Kirby, W.H., Schneider, V.R., and Flippo, H.N., 1986, Bridge waterways analysis model; research report: Federal Highway Administration Publication FHWA-RD-86-108, 112 p.

Talbot, A.N., 1887, The determination of water-way for bridges and culverts.

U.S. Department of Transportation, 1993, Stream stability and scour at highway bridges, Participant Workbook: Federal Highway Administration Publication FHWA HI-91-011.

U.S. Geological Survey, 1981, South Royalton, Vermont 7.5 Minute Series quadrangle map: U.S. Geological Survey Topographic Maps, Photoinspected 1983, Scale 1:24,000. 


\section{APPENDIX A: \\ WSPRO INPUT FILE}




\section{WSPRO INPUT FILE}

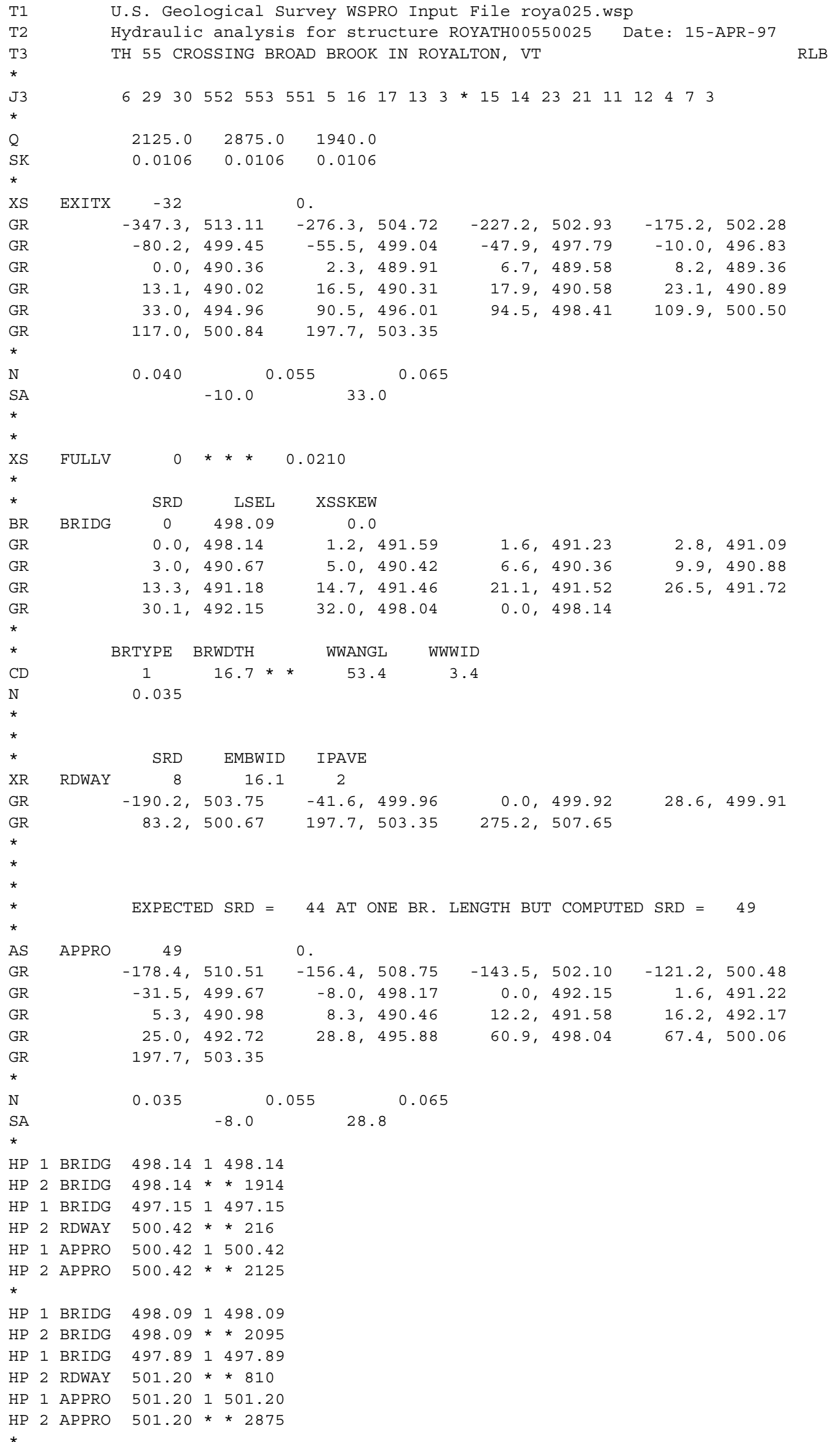




\section{APPENDIX B: \\ WSPRO OUTPUT FILE}


WSPRO OUTPUT FILE

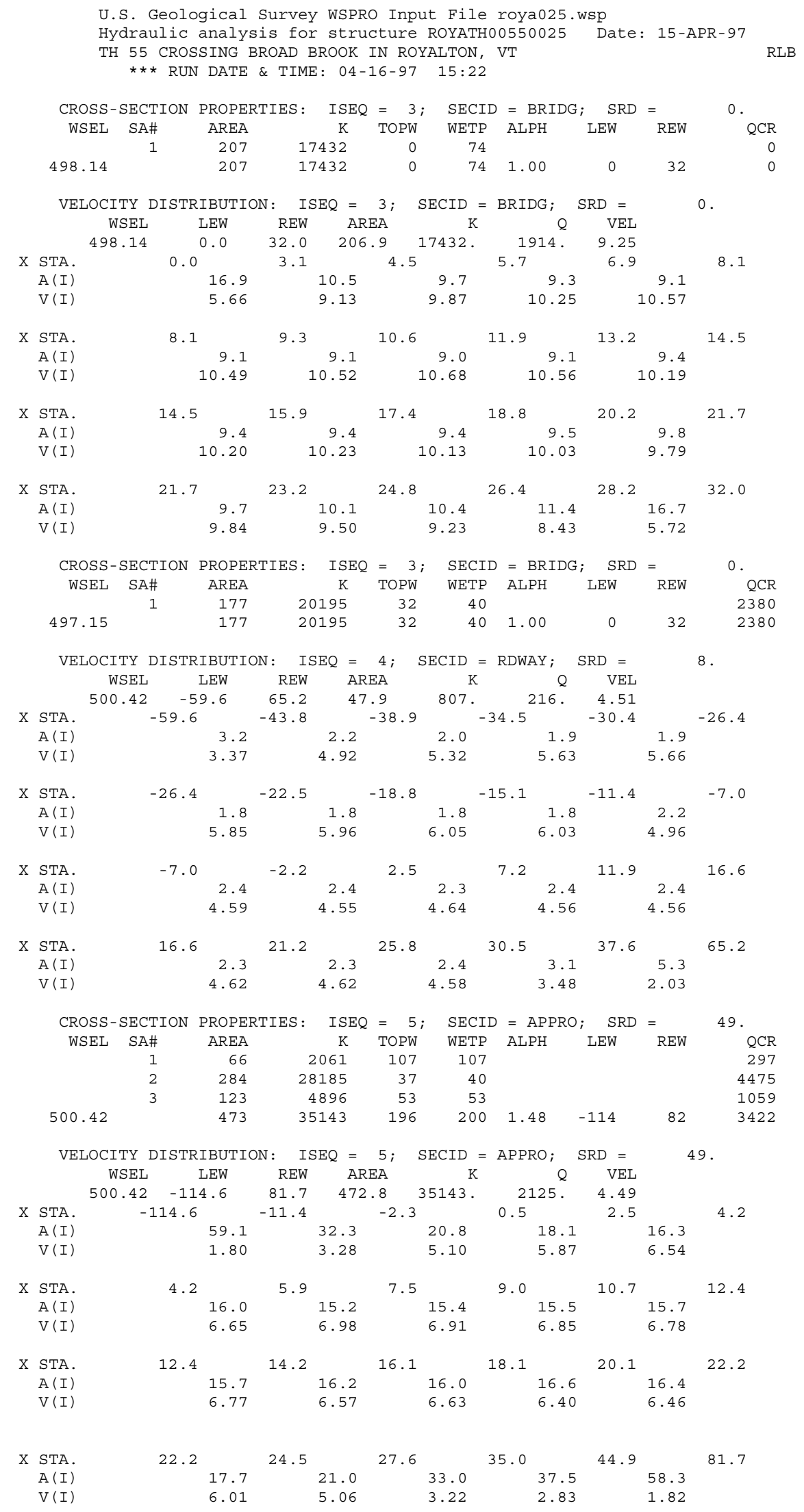


WSPRO OUTPUT FILE (continued)

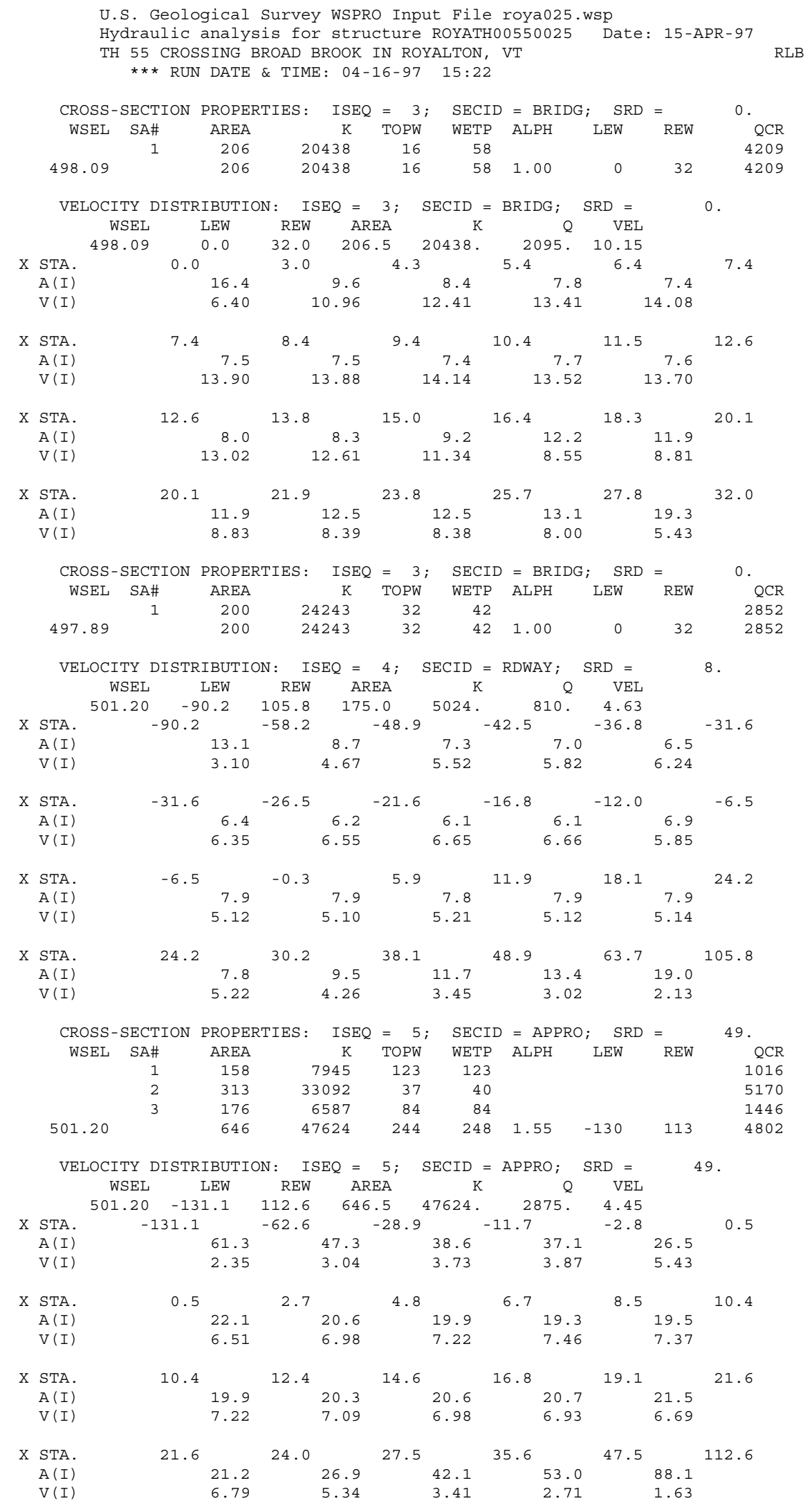


WSPRO OUTPUT FILE (continued)

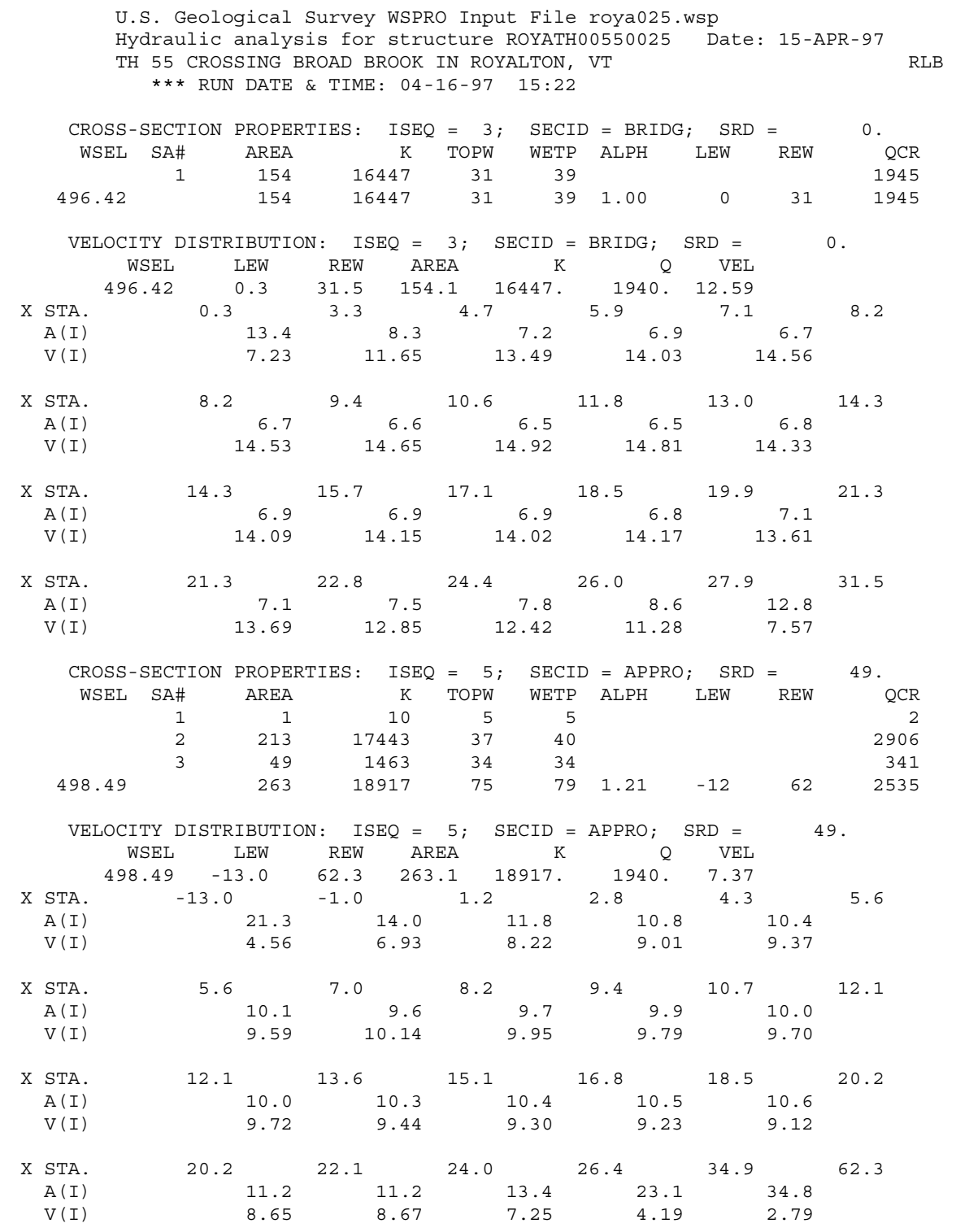


WSPRO OUTPUT FILE (continued)

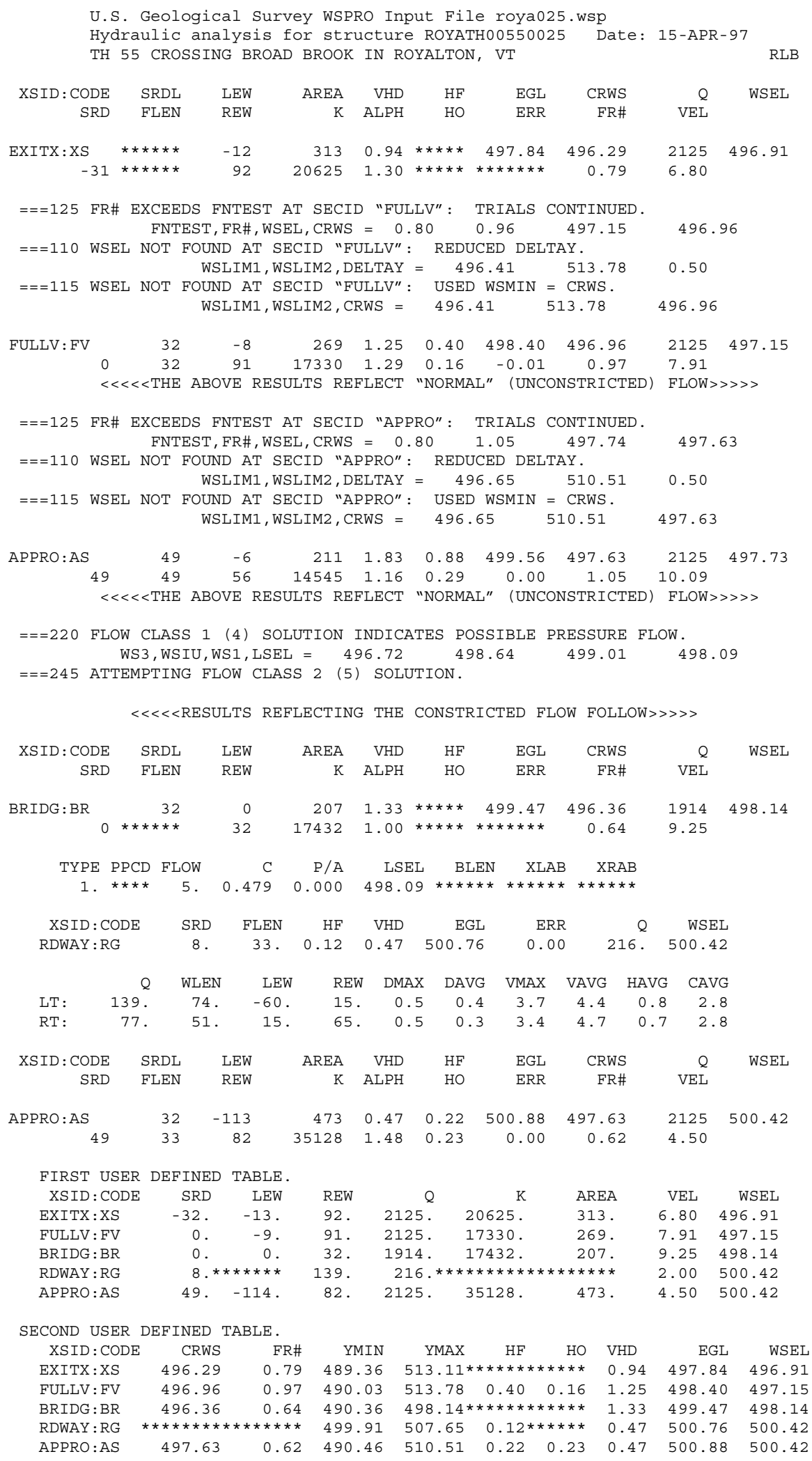


WSPRO OUTPUT FILE (continued)

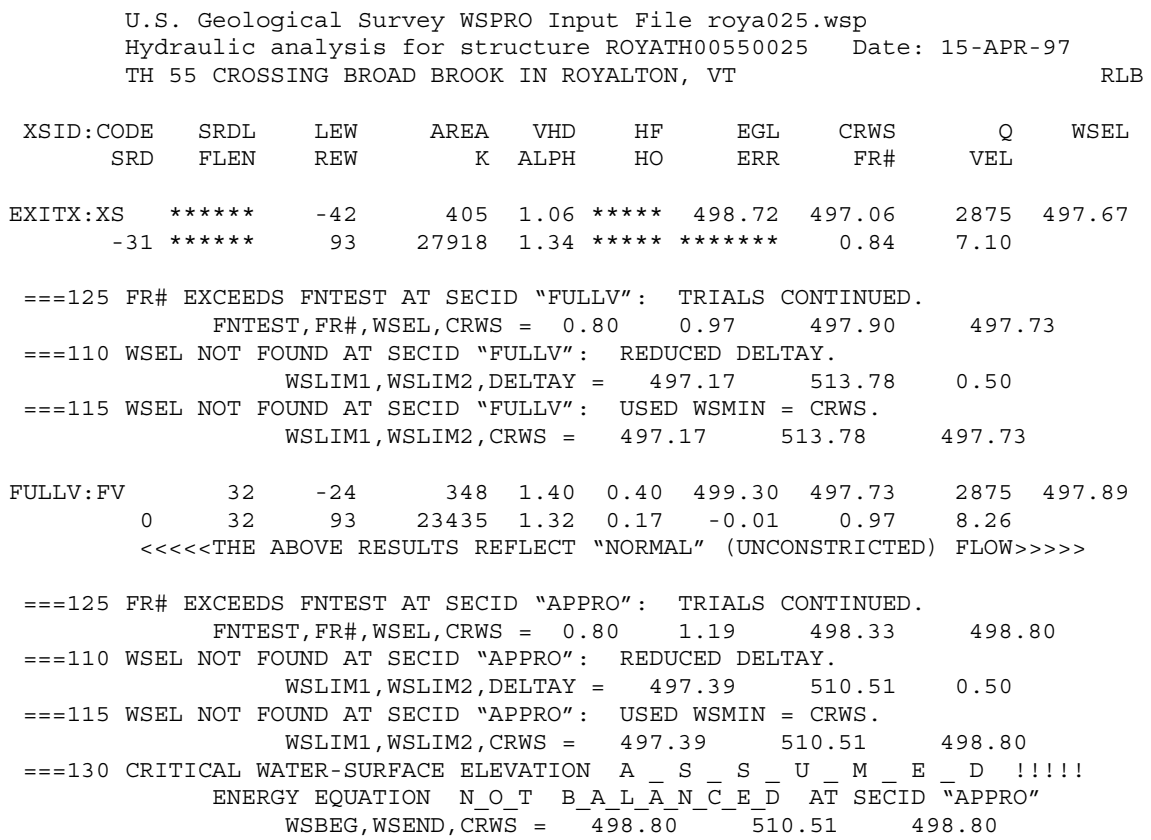


WSPRO OUTPUT FILE (continued)

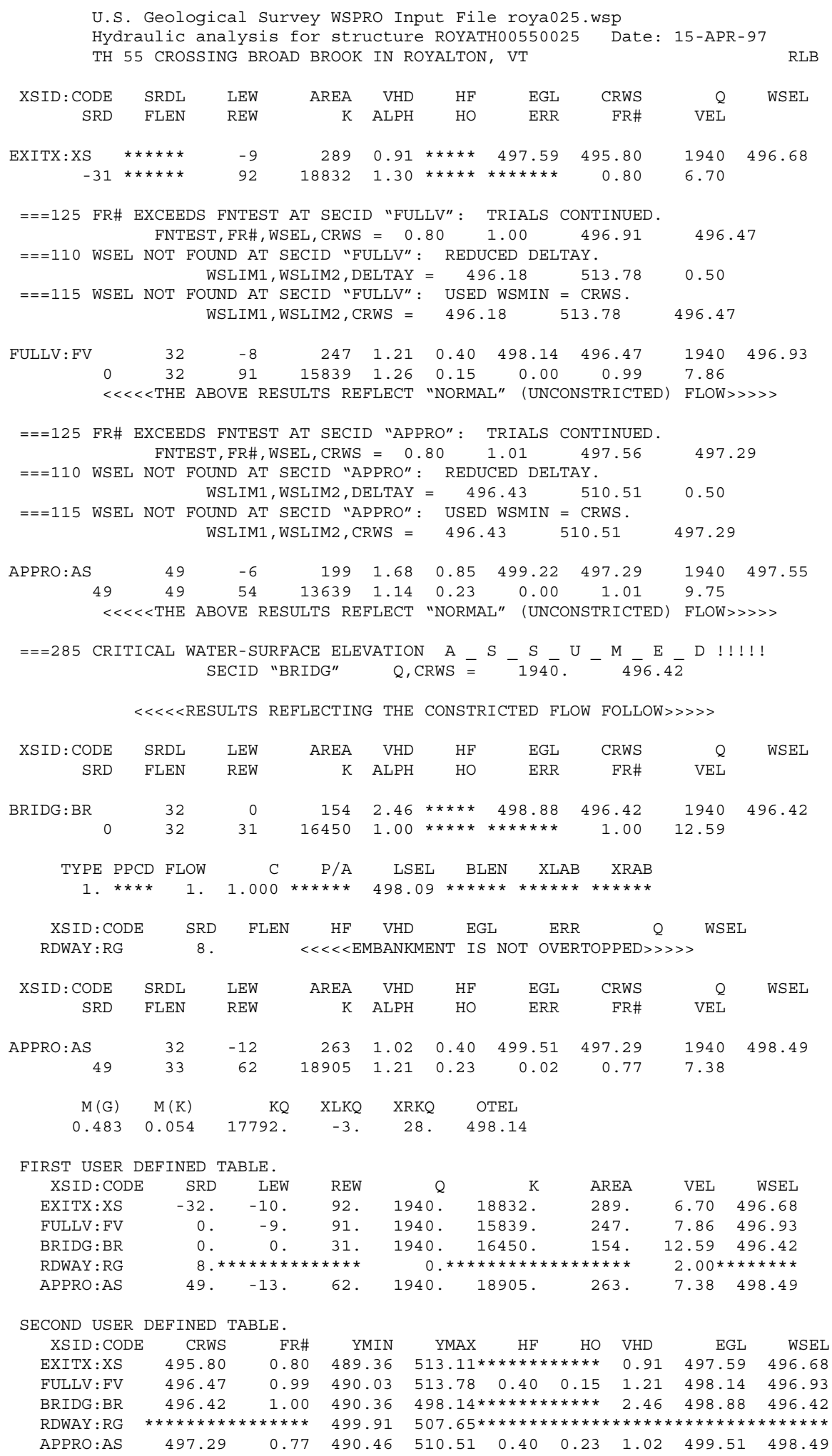




\section{APPENDIX C:}

\section{BED-MATERIAL PARTICLE-SIZE DISTRIBUTION}




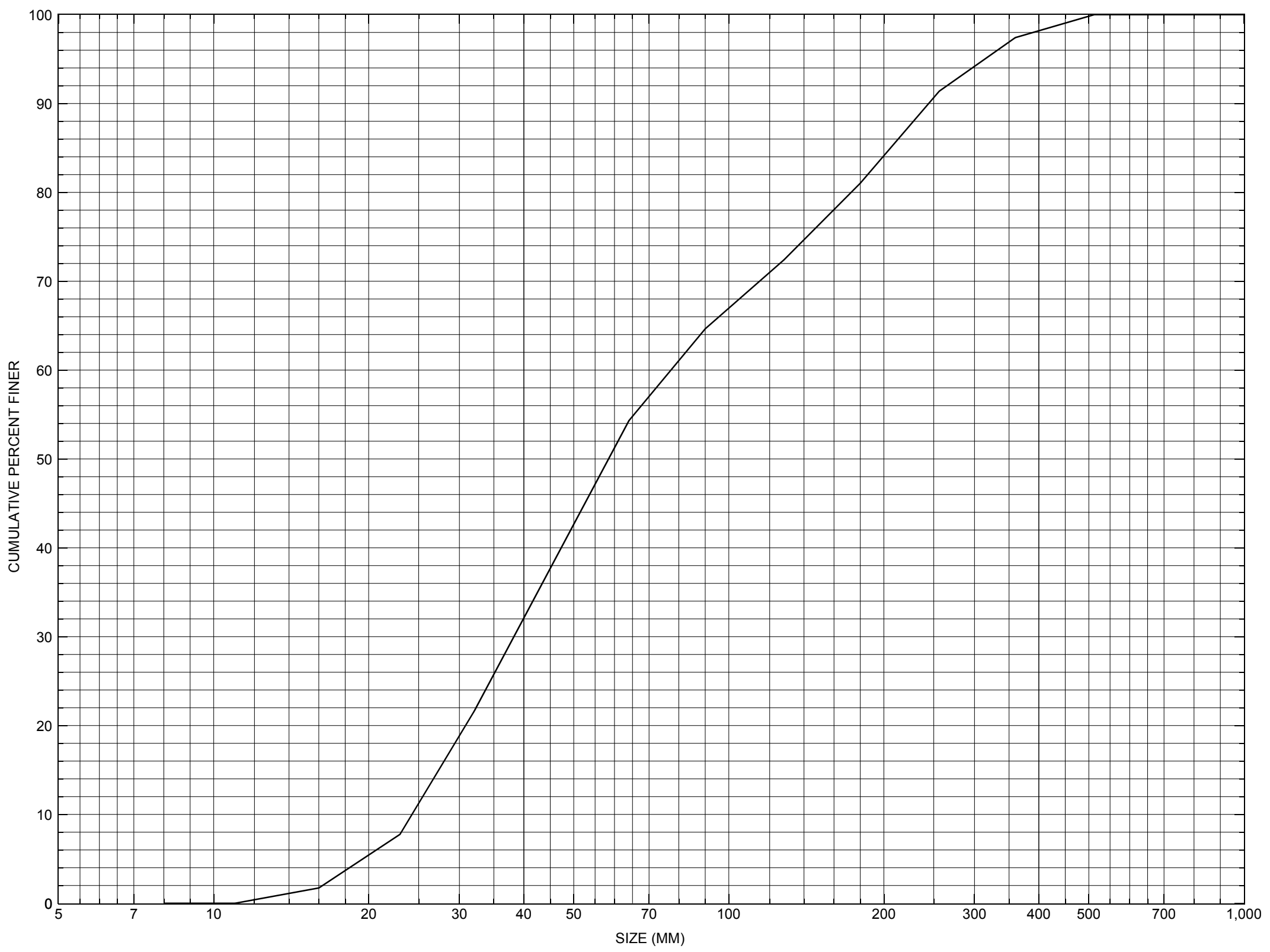

Appendix C. Bed material particle-size distribution for a pebble count in the channel approach of structure ROYATH00550025, in Royalton, Vermont. 


\section{APPENDIX D: \\ HISTORICAL DATA FORM}




\section{Structure Number ROYATH00550025}

\section{General Location Descriptive}

Data collected by (First Initial, Full last name) $\mathbf{E}$. BOEHMLER

Date $(M M / D D / Y Y) \_\mathbf{0 3} / \underline{22} / \underline{95}$

Highway District Number (I - 2; nn) $\mathbf{0 4}$

Town (FIPS place code; I - 4; nnnnn) $\mathbf{6 0 8 5 0}$

Waterway (I - 6) BROAD BROOK

Route Number TH055

Topographic Map South Royalton

Latitude (I - 16; nnnn.n) $\mathbf{4 3 4 6 1}$
County (FIPS county code; I - 3; nnn)

Mile marker (I - 11; nnn.nnn) $\mathbf{0 0 0 0 0 0}$

Road Name (I - 7): -

Vicinity (I - 9) AT JCT C2 TH 2 \& C3 TH55

Hydrologic Unit Code: $\mathbf{0 1 0 8 0 1 0 5}$

Longitude (i - 17; nnnnn.n) $\mathbf{7 2 3 1 7}$

\section{Select Federal Inventory Codes}

FHWA Structure Number (I - 8) 10141600251416

Maintenance responsibility $(I-21 ; n n) \quad \mathbf{0 3}$

Year built (I - 27; YYYY) 1933

Average daily traffic, ADT (I - 29; nnnnnn) 000010

Year of ADT (I - 30; YY) $\mathbf{9 0}$

Opening skew to Roadway $(I-34 ; n n) \quad \mathbf{0 0}$

Operational status $(I-41 ; X) \quad$ B

Structure type (I- 43; nnn) $\mathbf{3 0 2}$

Approach span structure type (I - 44; nnn) $\mathbf{0 0 0}$

Number of spans (I - 45; nnn) $\mathbf{0 0 1}$

Number of approach spans (I - 46; nnnn) $\mathbf{0 0 0 0}$

Comments:

The structural inspection report of 6/22/94 indicates the structure is a steel stringer type bridge with a timber deck. The abutment walls and wingwalls are concrete which are in like new condition except for a few minor stains. The right abutment footing is reported as not in view but the left abutment footing is visible at the surface and there is some localized scouring noted at the downstream end. The top of the footing is noted as between 2 and 2.5 feet above the adjacent streambed level. Although the left abutment footing is exposed, the report indicates no undermining or settling of the abutments or wingwalls. The top surface of the footing has some surface spalling noted, but no reinforcement bar is (Continued, page 33) 


\section{Bridge Hydrologic Data}

Is there hydrologic data available? $\underline{\mathbf{N}}$ if No, type ctrl-n $h \quad$ VTAOT Drainage area $\left(m i^{2}\right)$ : -

Terrain character:

Stream character \& type: -

Streambed material:

Discharge Data (cfs):

$$
\begin{aligned}
& Q_{2.33}- \\
& Q_{50}-
\end{aligned}
$$

Record flood date $(M M / D D / Y Y)$ :

Estimated Discharge (cfs): Ice conditions (Heavy, Moderate, Light) : -

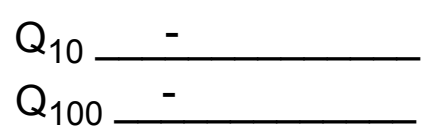

$$
\begin{aligned}
& Q_{25}- \\
& Q_{500}-
\end{aligned}
$$

Water surface elevation $(f t):-$

The stage increases to maximum highwater elevation (Rapidly, Not rapidly):

The stream response is (Flashy, Not flashy):

Describe any significant site conditions upstream or downstream that may influence the stream's stage: -

Watershed storage area (in percent): _ _ \%

The watershed storage area is: - (1-mainly at the headwaters; 2- uniformly distributed; 3-immediatly upstream oi the site)

Water Surface Elevation Estimates for Existing Structure:

\begin{tabular}{|l|l|l|l|l|l|}
\hline Peak discharge frequency & $Q_{2.33}$ & $Q_{10}$ & $Q_{25}$ & $Q_{50}$ & $Q_{100}$ \\
Water surface elevation (ft)) & - & - & - & - & - \\
Velocity (ft/sec) & - & - & - & - & - \\
\hline
\end{tabular}

Long term stream bed changes: -

Is the roadway overtopped below the $\mathrm{Q}_{100}$ ? (Yes, No, Unknown): $\mathbf{U}$ Frequency: Relief Elevation (ft): Discharge over roadway at $Q_{100}\left(f^{3} / \mathrm{sec}\right)$ :

Are there other structures nearby? (Yes, No, Unknown): $\underline{\mathbf{U}}$ Upstream distance (miles): Town: If No or Unknown, type ctrl-n os Highway No. : Structure No. : Year Built:

Clear span (ft): Clear Height $(f t)$ : Full Waterway $\left(f^{2}\right)$ : 
Downstream distance (miles): Town: Year Built:

Highway No. : Structure No. : Structure Type:

Clear span $(f t):$ Clear Height $(f t)$ : Full Waterway $\left(f^{2}\right)$ :

Comments:

visible. The report indicated the channel makes a moderate bend into the crossing. The channel is composed of stone and gravel with some medium sized boulders. The banks are noted as fairly well protected with natural streambed material. Debris accumulation and bank erosion are noted as not evident on the report.

\section{USGS Watershed Data}

Watershed Hydrographic Data

Drainage area (DA) 11.61

Watershed storage (ST)

Bridge site elevation

Main channel length 840 5.21 $10 \%$ channel length elevation $\mathrm{mi}^{2}$ $\mathbf{0}$ $\%$

Main channel slope (S) 143.32 $\mathrm{ft} / \mathrm{mi}$ mi

Lake and pond area

0 $\mathrm{mi}^{2}$ Headwater elevation 1958 $\mathrm{ft}$ $\mathrm{ft} \quad 85 \%$ channel length elevation $\mathrm{ft}$

Watershed Precipitation Data

Average site precipitation in Average headwater precipitation in

Maximum 2yr-24hr precipitation event $(124,2)$ in

Average seasonal snowfall (Sn) $\mathrm{ft}$ 


\section{Bridge Plan Data}

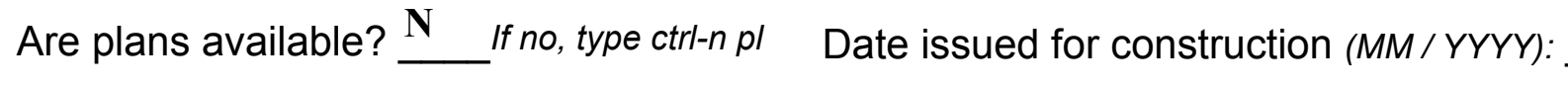

Project Number

Minimum channel bed elevation:

Low superstructure elevation: USLAB DSLAB USRAB DSRAB Benchmark location description:

NO BENCHMARK INFORMATION

Reference Point (MSL, Arbitrary, Other): Datum (NAD27, NAD83, Other):

Foundation Type: 4

If 1: Footing Thickness

If 2: Pile Type: (1-Wood; 2-Steel or metal; 3-Concrete)

If 3 : Footing bottom elevation:

Is boring information available? $\mathbf{N}$ If no, type ctrl-n bi Number of borings taken:

Foundation Material Type: $\mathbf{3}$ (1-regolith, 2-bedrock, 3-unknown)

Briefly describe material at foundation bottom elevation or around piles:

NO FOUNDATION MATERIAL INFORMATION

Comments:

NO PLANS. 


\section{Cross-sectional Data}

Is cross-sectional data available? Yes If no, type ctrl-n xs

Source (FEMA, VTAOT, Other)? VTAOT

The station and low cord to bed differences are from a sketch dated 6/22/94 that is attached to Comments: a bridge inspection report. The low cord elevations are from the 7/10/96 survey that was done for this report. This cross section is of the upstream face.

\begin{tabular}{|l|l|l|l|l|l|l|l|l|l|l|l|}
\hline Station & $\mathbf{0}$ & $\mathbf{1 . 3 3}$ & $\mathbf{1 . 3 4}$ & $\mathbf{6 . 3 4}$ & $\mathbf{1 5 . 5 0}$ & $\mathbf{3 1 . 0 0}$ & - & - & - & - & - \\
\hline Feature & LAB & - & - & - & - & RAB & - & - & - & - & - \\
\hline $\begin{array}{l}\text { Low cord } \\
\text { elevation }\end{array}$ & 498.14 & $\mathbf{4 9 8 . 1 4}$ & $\mathbf{4 9 8 . 1 4}$ & $\mathbf{4 9 8 . 1 2}$ & $\mathbf{4 9 8 . 0 9}$ & $\mathbf{4 9 8 . 0 4}$ & - & - & - & - & - \\
\hline $\begin{array}{l}\text { Bed } \\
\text { elevation }\end{array}$ & 491.34 & 491.34 & 489.34 & $\mathbf{4 8 9 . 9 2}$ & $\mathbf{4 9 1 . 0 9}$ & $\mathbf{4 9 1 . 8 4}$ & - & - & - & - & - \\
\hline $\begin{array}{l}\text { Low cord to } \\
\text { bed length }\end{array}$ & $\mathbf{6 . 8 0}$ & $\mathbf{6 . 8 0}$ & $\mathbf{8 . 8 0}$ & $\mathbf{8 . 2 0}$ & $\mathbf{7 . 0 0}$ & $\mathbf{6 . 2 0}$ & - & - & - & - & - \\
\hline Station & - & - & - & - & - & - & - & - & - & - & - \\
\hline Feature & - & - & - & - & - & - & - & - & - & - & - \\
\hline $\begin{array}{l}\text { Low cord } \\
\text { elevation }\end{array}$ & - & - & - & - & - & - & - & - & - & - & - \\
\hline $\begin{array}{l}\text { Bed } \\
\text { elevation }\end{array}$ & - & - & - & - & - & - & - & - & - & - & - \\
\hline $\begin{array}{l}\text { Low cord to } \\
\text { bed length }\end{array}$ & - & - & - & - & - & - & - & - & - & - & - \\
\hline
\end{tabular}

Source (FEMA, VTAOT, Other)?

Comments: -

\begin{tabular}{|l|l|l|l|l|l|l|l|l|l|l|l|}
\hline Station & - & - & - & - & - & - & - & - & - & - & - \\
\hline Feature & - & - & - & - & - & - & - & - & - & - & - \\
\hline $\begin{array}{l}\text { Low cord } \\
\text { elevation }\end{array}$ & - & - & - & - & - & - & - & - & - & - & - \\
\hline $\begin{array}{l}\text { Bed } \\
\text { elevation }\end{array}$ & - & - & - & - & - & - & - & - & - & - & - \\
\hline $\begin{array}{l}\text { Low cord to } \\
\text { bed length }\end{array}$ & - & - & - & - & - & - & - & - & - & - & - \\
\hline Station & - & - & - & - & - & - & - & - & - & - & - \\
\hline Feature & - & - & - & - & - & - & - & - & - & - & - \\
\hline $\begin{array}{l}\text { Low cord } \\
\text { elevation }\end{array}$ & - & - & - & - & - & - & - & - & - & - & - \\
\hline $\begin{array}{l}\text { Bed } \\
\text { elevation }\end{array}$ & - & - & - & - & - & - & - & - & - & - & - \\
\hline $\begin{array}{l}\text { Low cord to } \\
\text { bed length }\end{array}$ & - & - & - & - & - & - & - & - & - & - & - \\
\hline
\end{tabular}




\section{APPENDIX E: \\ LEVEL I DATA FORM}


U. S. Geological Survey

Bridge Field Data Collection and Processing Form

Qa/Qc Check by: $\underline{\mathbf{R B}}$ Date: $\underline{10 / 03 / 96}$

\section{Structure Number}

ROYATH00550025

Computerized by: $\underline{\mathbf{R B}}$ Date: $10 / 03 / 96$

Reviewd by: $\quad$ RB Date: $\underline{05 / 13 / 97}$

\section{A. General Location Descriptive}

1. Data collected by (First Initial, Full last name) M. WEBER

Date $(M M / D D / Y Y) \mathbf{0 4} / 13 / 1995$

2. Highway District Number 04

County $\mathbf{0 2 7}$

Waterway (l - 6) BROAD BROOK

Route Number TH055

Mile marker $\mathbf{0 0 0 0}$

Town 60850

Road Name -

Hydrologic Unit Code: $\mathbf{0 1 0 8 0 1 0 5}$

3. Descriptive comments:

Located at the junction of CL2 TH2 and CL3 TH55.

\section{B. Bridge Deck Observations}
4. Surface cover... LBUS 4
RBUS 6
LBDS 4
RBDS 6
Overall 6

(2b us,ds,lb,rb: 1- Urban; 2- Suburban; 3- Row crops; 4- Pasture; 5- Shrub- and brushland; 6- Forest; 7- Wetland)
5. Ambient water surface... US 2
UB 2
DS 2
(1- pool; 2- riffle)

6. Bridge structure type 1 (1- single span; 2- multiple span; 3- single arch; 4- multiple arch; 5-cylindrical culvert; 6- box culvert; or 7- other)
7. Bridge length $\mathbf{3 5}$
(feet)
Span length $\underline{\mathbf{3 1}}$
(feet)
Bridge width 16.1 (feet)

\section{Road approach to bridge:}
8. LB 0
RB 2
( 0 even, 1- lower, 2- higher)
9. LB_2
RB $\underline{2}$
(1- Paved, 2- Not paved)

10. Embankment slope (run / rise in feet / foot)

US left

US right

\begin{tabular}{|c|c|c|c|}
\hline \multicolumn{2}{|c|}{ Protection } & \multirow{2}{*}{ 13.Erosion } & 14.Severity \\
\hline 11.Type & 12.Cond. & $\underline{\mathbf{3}}$ & $\underline{\mathbf{2}}$ \\
\hline $\mathbf{1}$ & $-\mathbf{2}$ & $\underline{\mathbf{2}}$ & $\mathbf{1}$ \\
\hline $\mathbf{0}$ & - & $\underline{\mathbf{2}}$ & - \\
\hline $\mathbf{0}$ & - & $\underline{\mathbf{0}}$ & $\mathbf{1}$ \\
\hline $\mathbf{0}$ & - & $\underline{\mathbf{2}}$ & $\mathbf{1}$ \\
\hline
\end{tabular}

Bank protection types: 0- none; 1- < 12 inches;

2- < 36 inches; 3- < 48 inches;

4- < 60 inches; 5- wall / artificial levee

Bank protection conditions: 1- good; 2- slumped;

3- eroded; 4- failed

Erosion: 0 - none; 1- channel erosion; 2 -

road wash; 3- both; 4- other

Erosion Severity: 0 - none; 1- slight; 2- moderate; 3- severe

\section{Channel approach to bridge (BF):}

15. Angle of approach: $\mathbf{2 0}$

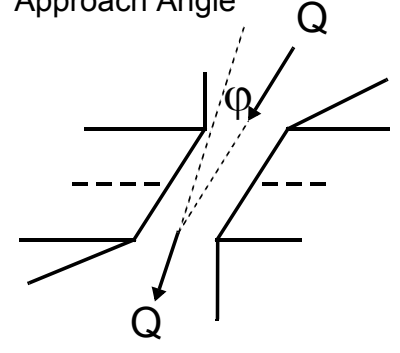

17. Channel impact zone 1:

Where? LB $(L B, R B)$

Range? 10 feet $\underline{\mathbf{U}}$

Channel impact zone 2:

Where? LB $(L B, R B)$

Range? $\underline{70}$ feet $\underline{\mathbf{U S}}$ (US, UB, DS) to $\underline{\mathbf{1 2 0}}$ feet $\underline{\mathbf{U S}}$

Impact Severity: 0- none to very slight; 1- Slight; 2- Moderate; 3- Severe
16. Bridge skew: $\mathbf{2 0}$ Bridge Skew Angle

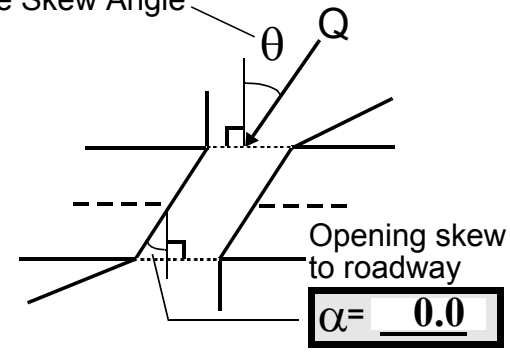

\section{Exist? $\mathbf{Y}(Y$ or $N)$}

Severity 2

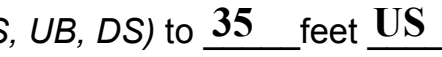

Exist? $\mathbf{Y}(\mathrm{Y}$ or $N)$

Severity 2 
18. Bridge Type: 1a

1a- Vertical abutments with wingwalls

$1 \mathrm{~b}$ - Vertical abutments without wingwalls

2- Vertical abutments and wingwalls, sloping embankment Wingwalls perpendicular to abut. face

3- Spill through abutments

4- Sloping embankment, vertical wingwalls and abutments

Wingwall angle less than $90^{\circ}$.
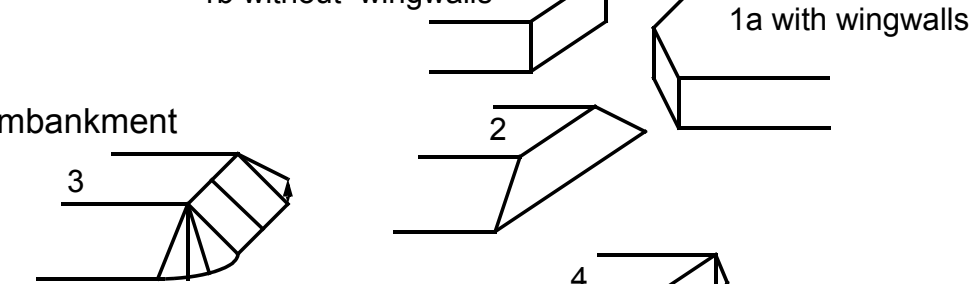

19. Bridge Deck Comments (surface cover variations, measured bridge and span lengths, bridge type variations, approach overflow width, etc.)

7. Values are from the VT AOT files. Measured bridge length is $32 \mathrm{ft}$, span length is $29 \mathrm{ft}$, and the bridge width is $16 \mathrm{ft}$.

18. The US wingwalls slope down to $0.5 \mathrm{ft}$ below the low chord.

4. Surface cover on the left bank is generally pasture while that on the right bank is forest. It is forest overall since the dominant watershed surface cover is forest. TH2 runs parallel to the stream along the immediate left bank.

17. The entire left bank US from $10 \mathrm{ft}$ under the bridge to $120 \mathrm{ft}$ US is a moderate impact zone.

11. Gravel road fill material is apparent at all road approaches down the bank.

\section{Upstream Channel Assessment}

\begin{tabular}{|c|c|c|c|c|c|c|c|c|c|c|}
\hline & \multicolumn{2}{|c|}{ 21. Bank height ( $\mathrm{BF}$ ) 22. Bank anqle (BF) } & 22. $\mathrm{B}$ & gle $(B F)$ & \multicolumn{2}{|c|}{ 26. \% Veg. cover (BF) } & \multicolumn{2}{|c|}{ 27. Bank material (BF) } & \multicolumn{2}{|c|}{ 28. Bank erosion (BF) } \\
\hline 20. SRD & LB & $\mathrm{RB}$ & LB & RB & LB & $\mathrm{RB}$ & LB & RB & LB & $\mathrm{RB}$ \\
\hline 33.5 & 6. & & & 3.0 & 1 & 4 & 3245 & 3245 & 2 & 1 \\
\hline 23. Bank & & & 24. $C$ & width & 35.0 & 25. Tha & weg depth & 37.5 & 29. Bec & 345 \\
\hline
\end{tabular}

\section{0 .Bank protection type:}

LB 2

RB 0

31. Bank protection condition: LB 1

$\mathrm{RB}$ -

SRD - Section ref. dist. to US face \% Vegetation (Veg) cover: 1- 0 to 25\%; 2- 26 to 50\%; 3- 51 to $75 \%$; 4- 76 to $100 \%$

Bed and bank Material: 0- organics; 1- silt / clay, <1/16mm; 2- sand, 1/16 - 2mm; 3- gravel, 2 - 64mm;

4- cobble, 64 - 256mm; 5- boulder, > 256mm; 6- bedrock; 7- manmade

Bank Erosion: 0- not evident; 1- light fluvial; 2- moderate fluvial; 3- heavy fluvial / mass wasting

Bank protection types: 0- absent; 1- < 12 inches; 2- < 36 inches; 3- < 48 inches; 4- < 60 inches; 5- wall / artificial levee

Bank protection conditions: 1- good; 2- slumped; 3- eroded; 4- failed

32. Comments (bank material variation, minor inflows, protection extent, etc.):

26. The percent vegetation cover on the US right bank is 4 though the immediate bank vegetation cover is brushy and the trees are set back.

27. Bank material is gravel, sand, cobble and boulder.

29. Bed material is gravel, cobble and boulder.

28. The US left bank is an impact zone from $70 \mathrm{ft}$ US to $120 \mathrm{ft}$ US.

30. Left bank protection is native boulders placed by man from the US end of the US left wingwall to $120 \mathrm{ft}$ US.

A minor culvert inflow occurs $120 \mathrm{ft}$ US on the left bank. 

feet US (US, UB) to 90 feet $\underline{\mathbf{U S}}$

37. Material: 234

38. Point or side bar comments (Circle Point or Side; Note additional bars, material variation, status, etc.):

Bar material is sand and gravel with some cobbles.

39. Is a cut-bank present? $\mathbf{Y}$ (Y or if $N$ type $c t r l-n c b)$

41. Mid-bank distance: $\mathbf{8 5}$

43. Bank damage: 2

42. Cut bank extent: 25
40. Where? $\mathbf{L B} \quad(L B$ or $R B)$ feet $\underline{\mathbf{U S}}$ (US, UB) to $\underline{\mathbf{1 2 0}}$ feet $\underline{\mathbf{U S}}$ (US, UB, DS)

44. Cut bank comments (eg. additional cut banks, protection condition, etc.):

Road fill is slumping into the channel. There is man placed natural boulder protection on the bank. The slip failures are many small slumps rather than one large area of failure. These slumps occur along the left bank where the road embankment for $\mathbf{T H} 2$ is steep.

45. Is channel scour present? $\mathbf{N}$ ( $Y$ or if $N$ type ctrl-n cs) 46. Mid-scour distance: -

47. Scour dimensions: Length ___ Width _ _ Depth : ___ Position __ $\%$ LB to _ _ $\%$ RB

48. Scour comments (eg. additional scour areas, local scouring process, etc.):

NO CHANNEL SCOUR

49. Are there major confluences? $\mathbf{N}$

51. Confluence 1: Distance Confluence 2: Distance 52. Enters on Enters on 54. Confluence comments (eg. confluence name):

NO MAJOR CONFLUENCES
50. How many? -

53. Type(1- perennial; 2- ephemeral)

Type (1-perennial; 2- ephemeral)

\section{Under Bridge Channel Assessment}

55. Channel restraint (BF)? LB 2

\begin{tabular}{|ccccc}
\hline \multicolumn{2}{|c}{56. Height (BF) } & \multicolumn{3}{c}{57 Angle (BF) } \\
LB & RB & LB & RB \\
$\mathbf{2 5 . 0}$ & & & $\mathbf{1 . 5}$ & \\
\hline
\end{tabular}
(1- natural bank; 2- abutment; 3- artificial levee)

58. Bank width (BF) 59. Channel width (Amb) -

61. Material (BF)

LB RB

$\underline{2} \quad \underline{7}$
62. Erosion (BF)

LB RB

7
63. Bed Material -

Bed and bank Material: 0- organics; 1- silt / clay, < 1/16mm; 2- sand, 1/16 - 2mm; 3- gravel, 2 - 64mm; 4- cobble, 64 - 256mm; 5- boulder, > 256mm; 6- bedrock; 7- manmade

Bank Erosion: 0- not evident; 1- light fluvial; 2- moderate fluvial; 3- heavy fluvial / mass wasting

64. Comments (bank material variation, minor inflows, protection extent, etc.):

3452

63. Bed material is gravel, cobble, boulder and some sand. 
65. Debris and Ice Is there debris accumulation?

$(Y$ or $N)$ 66. Where? $\mathbf{N}$

(1- Upstream; 2- At bridge; 3- Both)

67. Debris Potential ( 1- Low; 2- Moderate; 3- High)

68. Capture Efficiency 2

(1-Low; 2- Moderate; 3- High)

69. Is there evidence of ice build-up? 2

Ice Blockage Potential $\mathbf{N}$

(1- Low; 2- Moderate; 3- High)

70. Debris and Ice Comments:

2

There are some logs caught on the DS left bank but no debris is apparent US or at the bridge. Capture efficiency is moderate due to the impact at the US left end of the substructure.

\begin{tabular}{|l|c|c|c|c|c|c|c|c|}
\hline Abutments & $\begin{array}{c}\text { 71. Attack } \\
\angle \text { (BF) }\end{array}$ & $\begin{array}{c}72 \text {. Slope } \angle \\
\text { (Qmax) }\end{array}$ & $\begin{array}{c}\text { 73. Toe } \\
\text { loc. (BF) }\end{array}$ & $\begin{array}{c}\text { 74. Scour } \\
\text { Condition }\end{array}$ & $\begin{array}{c}75 . \text { Scour } \\
\text { depth }\end{array}$ & $\begin{array}{c}\text { 76. Exposure } \\
\text { depth }\end{array}$ & 77. Material & 78. Length \\
\hline LABUT & & $\mathbf{2 0}$ & $\mathbf{9 0}$ & $\mathbf{2}$ & $\mathbf{2}$ & $\mathbf{1}$ & $\mathbf{2 . 5}$ & $\mathbf{9 0 . 0}$ \\
\hline RABUT & $\mathbf{1}$ & $\mathbf{0}$ & $\mathbf{9 0}$ & & & $\mathbf{2}$ & $\mathbf{0}$ & $\mathbf{3 2 . 0}$ \\
\hline
\end{tabular}

Pushed: $L B$ or RB

Toe Location (Loc.): 0- even, 1- set back, 2- protrudes

Scour cond.: 0- not evident; 1- evident (comment); 2- footing exposed; 3-undermined footing; 4- piling exposed; 5- settled; 6- failed

Materials: 1- Concrete; 2- Stone masonry or drywall; 3- steel or metal; 4- wood

79. Abutment comments (eg. undermined penetration, unusual scour processes, debris, etc.):

$-$

1

The left abutment footing is exposed its entire length but the maximum scour is at the DS end. Scour depth was calculated using an US average thalweg depth of $1.5 \mathrm{ft}$. There is some spalling of the left abutment footing its whole length. The spalling is most severe, $0.25 \mathrm{ft}$, on top of the footing's US end lessening the apparent exposure depth.

80. Wingwalls:

Exist? Material? Scour Scour Exposure $\begin{array}{lll}81 . & & \\ \text { Angle? Length? }\end{array}$

USLWW:

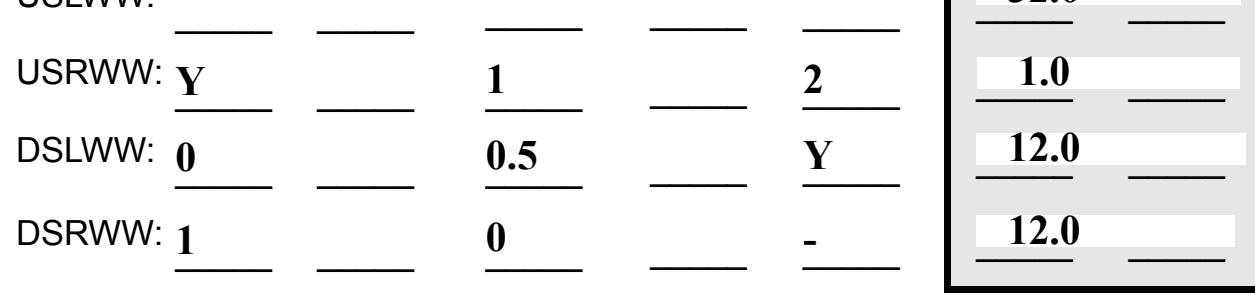

Wingwall materials: 1- Concrete; 2- Stone masonry or drywall; 3- steel or metal; 4- wood

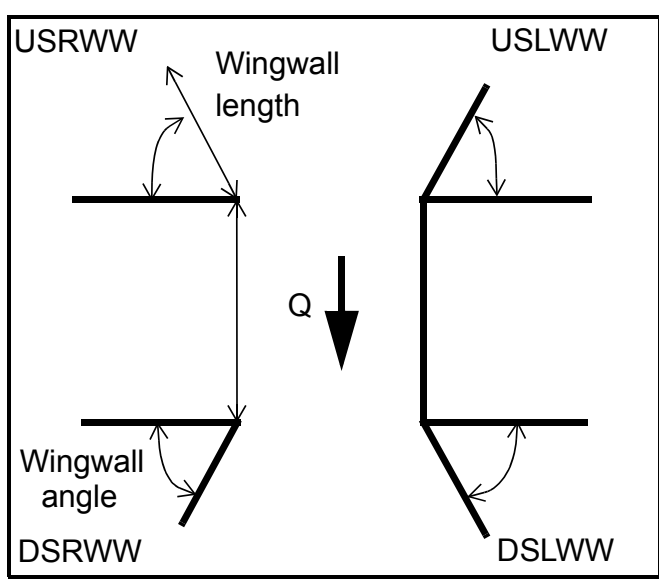

82. Bank / Bridge Protection:

\begin{tabular}{|l|l|l|l|l|l|l|c|c|}
\hline Location & USLWW & USRWW & LABUT & RABUT & LB & RB & DSLWW & DSRWW \\
\hline Type & - & $\mathbf{2}$ & Y & - & $\mathbf{1}$ & - & - & - \\
\hline Condition & $\mathbf{Y}$ & $\mathbf{1}$ & $\mathbf{1}$ & - & $\mathbf{2}$ & - & - & - \\
\hline Extent & $\mathbf{1}$ & $\mathbf{2 . 5}$ & $\mathbf{0}$ & $\mathbf{2}$ & $\mathbf{0}$ & $\mathbf{0}$ & $\mathbf{0}$ & - \\
\hline
\end{tabular}

Bank / Bridge protection types: 0- absent; 1- < 12 inches; 2- < 36 inches; 3- < 48 inches; 4- < 60 inches; 
83. Wingwall and protection comments (eg. undermined penetration, unusual scour processes, etc.):

-
-
-
-
-
2
1
3
0
-
-

\section{Piers:}

84. Are there piers? Th (Y or if $N$ type ctrl-n pr)

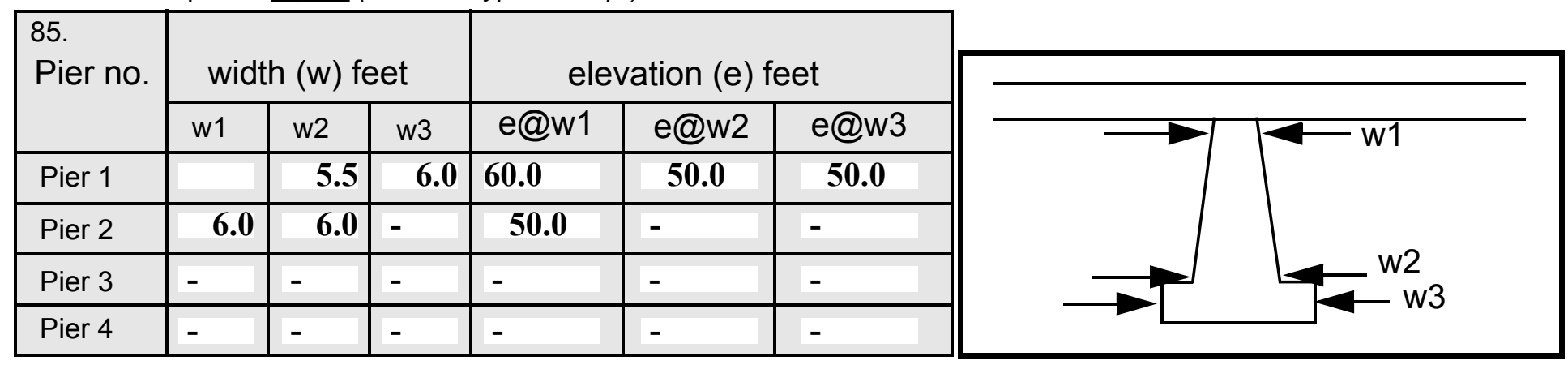

\begin{tabular}{|l|l|l|l|l|}
\hline Level 1 Pier Descr. & \multicolumn{1}{|c|}{1} & \multicolumn{1}{|c|}{2} & \multicolumn{1}{|c|}{3} & \multicolumn{1}{|c|}{4} \\
\hline 86. Location (BF) & e DS & ing is & $\mathbf{0 . 2 5} \mathbf{f t}$ & ing \\
\hline 87. Type & end & spall & less. & had \\
\hline 88. Material & of & ed & The & occu \\
\hline 89. Shape & the & mak- & expo & rred. \\
\hline 90. Inclined? & top & ing & sure & Pro- \\
\hline 91. Attack $\angle$ (BF) & of & the & dept & tec- \\
\hline 92. Pushed & the & appa & h is & tion \\
\hline 93. Length (feet) & - & - & - & - \\
\hline 94. \# of piles & US & rent & reco & in all \\
\hline 95. Cross-members & left & expo & rded & cases \\
\hline 96. Scour Condition & wing & sure & as if & is \\
\hline 97. Scour depth & wall & dept & no & man \\
\hline 98. Exposure depth & foot- & h & spall & place \\
\hline
\end{tabular}

LFP, LTB, LB, MCL, MCM, MCR, RB, RTB, RFP

1- Solid pier, 2- column, 3- bent

1-Wood; 2- concrete; 3- metal; 4- stone

1- Round; 2- Square; 3- Pointed

Y-yes; $N$ - no

$L B$ or $R B$

0- none; 1- laterals; 2- diagonals; 3- both

0- not evident; 1- evident (comment);

2- footing exposed; 3- piling exposed;

4- undermined footing; 5- settled; 6-failed 
99. Pier comments (eg. undermined penetration, protection and protection extent, unusual scour processes, etc.): d native stone. There is some spalling of the DS left wingwall footing as well.

$\mathbf{N}$

100.

\section{E. Downstream Channel Assessment}

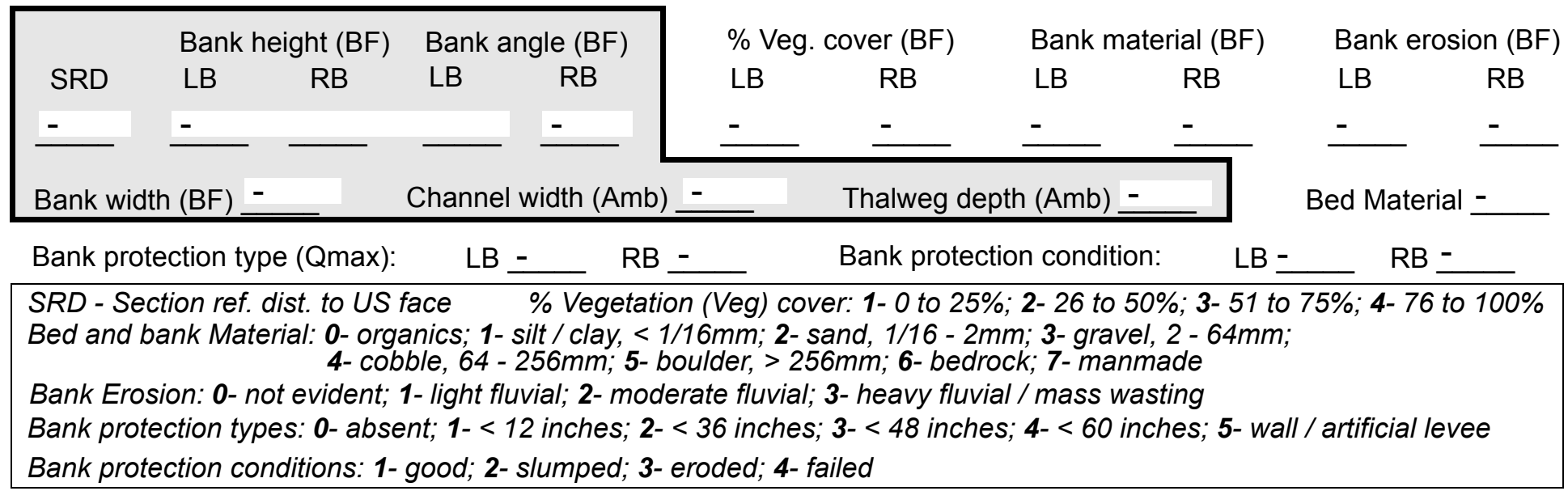

Comments (eg. bank material variation, minor inflows, protection extent, etc.):

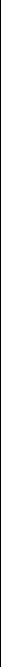

\section{Is a drop structure present? __ ( $Y$ or $N$, if $N$ type ctrl-n $d s) \quad$ 102. Distance: ___ feet}

103. Drop: -_ feet 104. Structure material: ___ (1- steel sheet pile; 2- wood pile; 3- concrete; 4- other)

105. Drop structure comments (eg. downstream scour depth): 
106. Point/Side bar present? (Y or $N$. if $N$ type ctrl-n pb)Mid-bar distance:

Mid-bar width: -

Point bar extent: feet -

(US, UB, DS) to feet (US, UB, DS) positioned $\%$ LB to $\% \mathrm{RB}$ Material:

Point or side bar comments (Circle Point or Side; note additional bars, material variation, status, etc.):

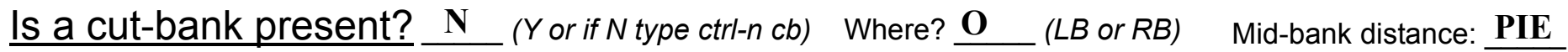
Cut bank extent: RS feet__ (US, UB, DS) to feet (US, UB, DS)

Bank damage: (1- eroded and/or creep; 2- slip failure; 3- block failure)

Cut bank comments (eg. additional cut banks, protection condition, etc.):

Is channel scour present? ( $Y$ or if $N$ type ctrl-n cs) Width 3245 Depth: 3245 Scour dimensions: Length 4

Scour comments (eg. additional scour areas, local scouring process, etc.): 3425

2 0 1

Are there major confluences? Confluence 1: Distance $\underline{\mathbf{k}}$ Confluence 2: Distance is Enters on mat (LB or RB) Enters on grav (LB or $R B)$ Mid-scour distance: 1 Positioned $\underline{1} \%$ LB to $\underline{1} \%$ RB Confluence comments (eg. confluence name):

sand, cobble and boulder. There is moderate bank erosion on the left bank DS starting at $130 \mathrm{ft}$ DS. The bed material is gravel, cobble, sand and boulder. The left bank protection is native boulders man placed from the

\section{F. Geomorphic Channel Assessment}

107. Stage of reach evolution en
1- Constructed

2- Stable

3- Aggraded

4- Degraded

5- Laterally unstable

6- Vertically and laterally unstable 
108. Evolution comments (Channel evolution not considering bridge effects; See HEC-20, Figure 1 for geomorphic descriptors):

d of the DS left wingwall to $120 \mathrm{ft}$ DS. 


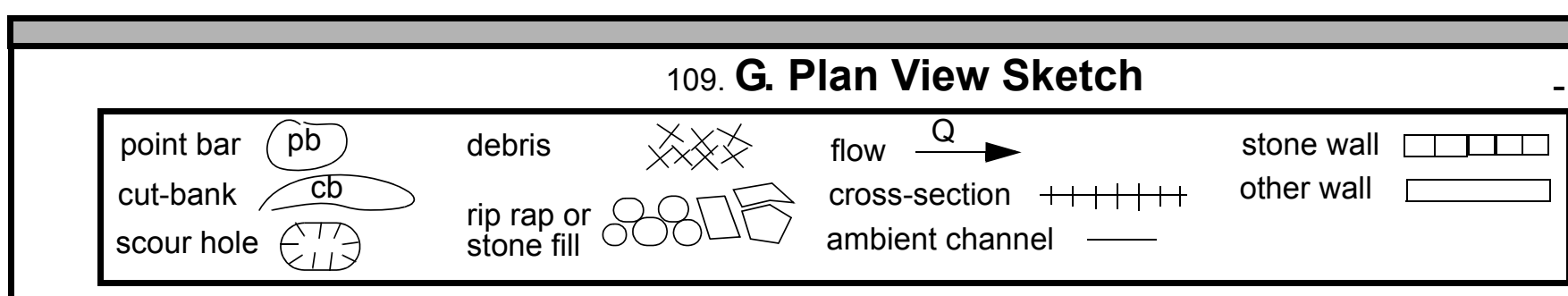


APPENDIX F:

SCOUR COMPUTATIONS 


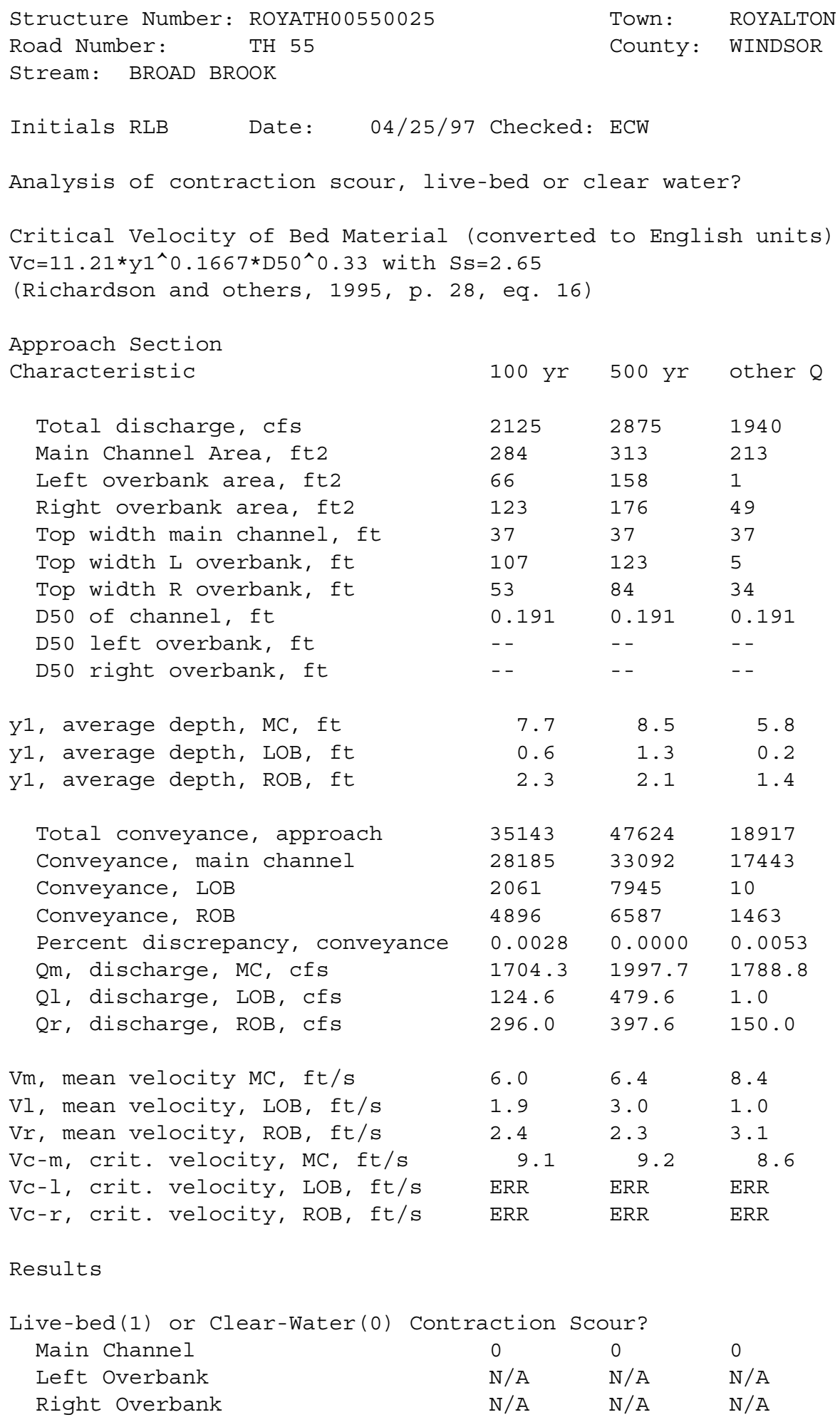


Clear water Contraction Scour in MAIN CHANNEL

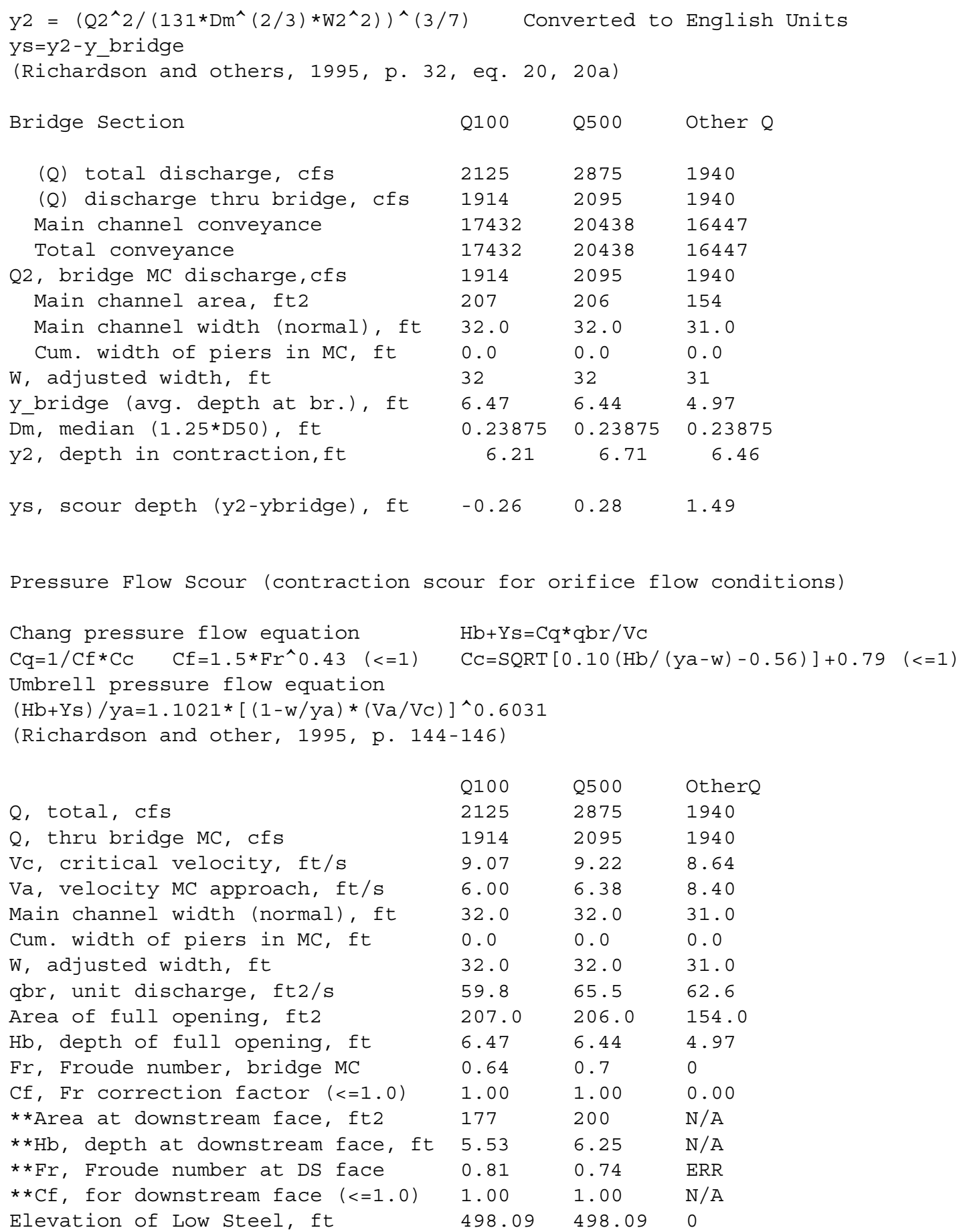




\begin{tabular}{|c|c|c|c|}
\hline Elevation of Bed, ft & 491.62 & 491.65 & -4.97 \\
\hline Elevation of Approach, ft & 500.42 & 501.2 & 0 \\
\hline Friction loss, approach, ft & 0.22 & 0.21 & 0.4 \\
\hline Elevation of WS immediately US, ft & 500.20 & 500.99 & -0.40 \\
\hline ya, depth immediately US, ft & 8.58 & 9.34 & 4.57 \\
\hline Mean elevation of deck, ft & 499.92 & 499.92 & 0 \\
\hline w, depth of overflow, ft $(>=0)$ & 0.28 & 1.07 & 0.00 \\
\hline Cc, vert contrac correction $(<=1.0)$ & 0.94 & 0.94 & 1.00 \\
\hline$* * \mathrm{Cc}$, for downstream face $(<=1.0)$ & 0.893207 & 0.92999 & ERR \\
\hline Ys, scour w/Chang equation, ft & 0.56 & 1.14 & $\mathrm{~N} / \mathrm{A}$ \\
\hline Ys, scour w/Umbrell equation, ft & 0.76 & 1.22 & $\mathrm{~N} / \mathrm{A}$ \\
\hline \multicolumn{4}{|l|}{ **=for UNsubmerged orifice flow only. } \\
\hline ang equation, ft & 1.85 & 1.39 & $\mathrm{~N} / \mathrm{A}$ \\
\hline **Ys, scour w/Umbrell equation, ft & 1.69 & 1.41 & ERR \\
\hline
\end{tabular}

In UNsubmerged orifice flow, an adjusted scour depth using the Laursen equation results and the estimated downstream bridge face properties can also be computed (ys=y2-ybridgeDs)

$\begin{array}{llll}\text { Y2, from Laursen's equation, ft } & 6.21 & 6.71 & 6.46 \\ \text { WSEL at downstream face, ft } & 497.15 & 497.89 & 0.00 \\ \text { Depth at downstream face, ft } & 5.53 & 6.24 & 4.97 \\ \text {, depth of scour (Laursen), ft } & 0.68 & 0.48 & \text { N/A }\end{array}$

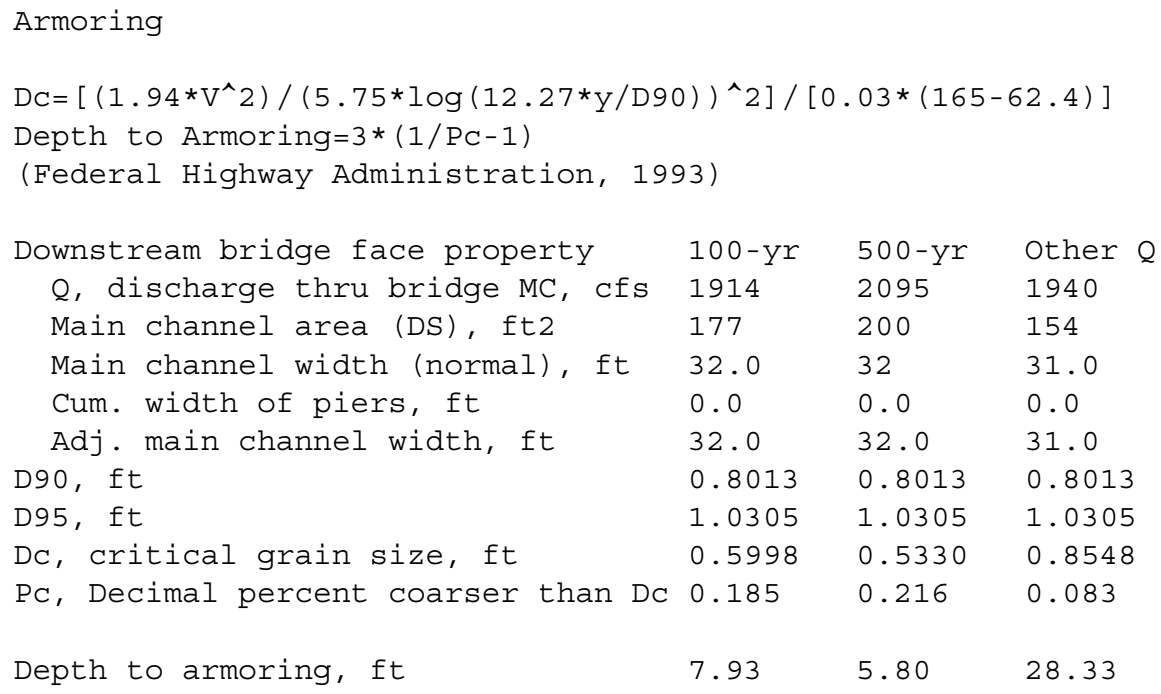




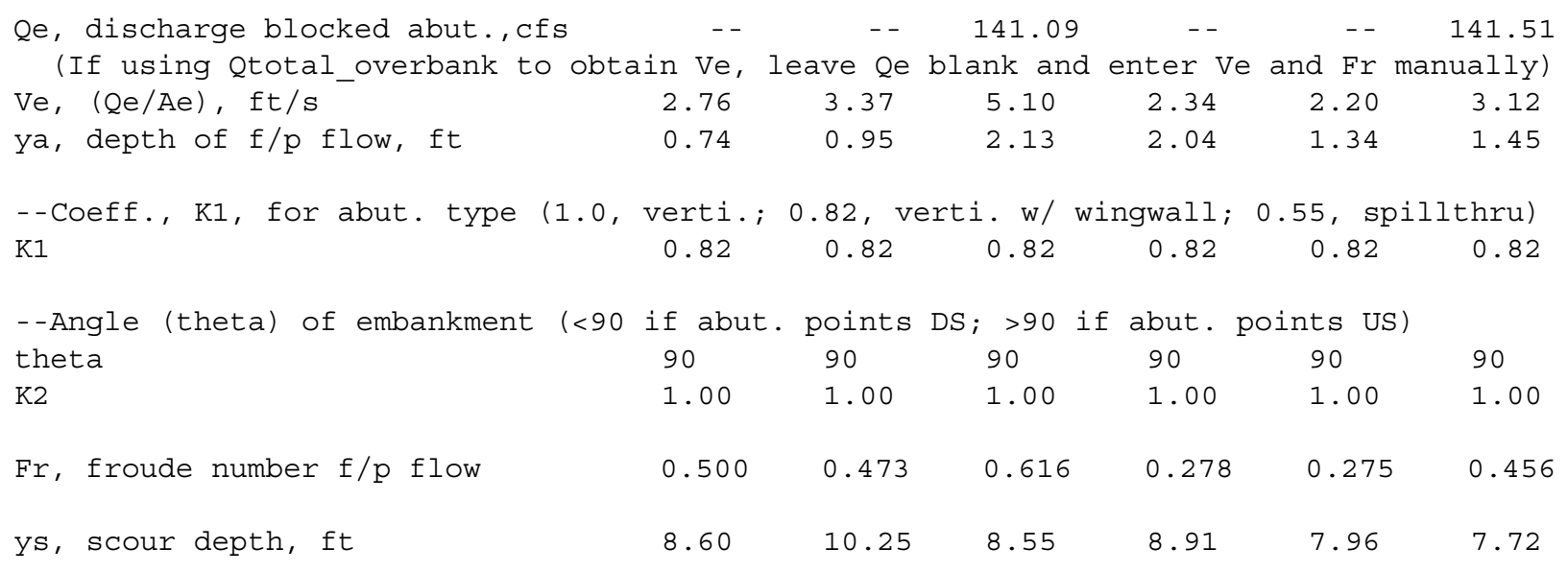

\begin{tabular}{|c|c|c|c|c|c|c|}
\hline \multicolumn{7}{|c|}{$\begin{array}{l}\text { HIRE equation }\left(a^{\prime} / \mathrm{ya}>25\right) \\
\text { Ys }=4 * \mathrm{Fr}^{\wedge} 0.33^{*} \mathrm{Y} 1 * \mathrm{~K} / 0.55 \\
(\mathrm{Richardson} \text { and others, 1995, p. 49, eq. 29) }\end{array}$} \\
\hline$a^{\prime}$ (abut length blocked, ft) & 114.6 & 131.1 & 13 & 49.7 & 80.6 & 31.3 \\
\hline y1 (depth f/p flow, ft) & 0.74 & 0.95 & 2.13 & 2.04 & 1.34 & 1.45 \\
\hline$a^{\prime} / y^{1}$ & 155.66 & 138.38 & 6.11 & 24.35 & 59.95 & 21.58 \\
\hline Skew correction (p. 49, fig. 16) & 1.00 & 1.00 & 1.00 & 1.00 & 1.00 & 1.00 \\
\hline Froude no. f/p flow & 0.50 & 0.47 & 0.62 & 0.28 & 0.28 & 0.46 \\
\hline \\
\hline vertical w/ $\mathrm{ww}^{\prime} \mathrm{s}$ & 3.49 & 4.41 & $\mathrm{ERR}$ & $\begin{array}{l}\text { ERR } \\
E R R\end{array}$ & 5.24 & $\mathrm{ERR}$ \\
\hline spill-through & 2.34 & 2.96 & ERR & ERR & 3.51 & ERR \\
\hline \multicolumn{7}{|l|}{ Abutment riprap Sizing } \\
\hline \multirow{2}{*}{\multicolumn{7}{|c|}{$\begin{array}{l}\text { Isbash Relationship } \\
\mathrm{D} 50=\mathrm{Y}^{\star} \mathrm{K} * \mathrm{Fr} \mathrm{F}^{\wedge} /(\mathrm{Ss}-1) \text { and } \mathrm{D} 50=\mathrm{Y}^{*} \mathrm{~K} *\left(\mathrm{Fr} r^{\wedge} 2\right)^{\wedge} 0.14 /(\mathrm{Ss}-1) \\
\text { (Richardson and others, 1995, p112, eq. 81,82) }\end{array}$}} \\
\hline & & & & & & \\
\hline Downstream bridge face property & Q100 & Q500 & Other $Q$ & Q100 & Q500 & Other $Q$ \\
\hline Fr, Froude Number & 0.81 & 0.74 & 1 & 0.81 & 0.74 & 1 \\
\hline$y$, depth of flow in bridge, ft & 5.53 & 6.25 & 4.97 & 5.53 & 6.25 & 4.97 \\
\hline \multicolumn{7}{|c|}{ Median stone Diameter for riprap at: left abutment } \\
\hline Fr $<=0.8$ (vertical abut.) & ERR & 2.12 & ERR & ERR & 2.12 & $\mathrm{ERR}$ \\
\hline Fr>0.8 (vertical abut.) & 2.18 & ERR & 2.08 & 2.18 & ERR & 2.08 \\
\hline
\end{tabular}


